\title{
Characterization of genetic rearrangements in esophageal squamous carcinoma cell lines by a combination of M-FISH and array-CGH: further confirmation of some split genomic regions in primary tumors
}

Jia-Jie Hao ${ }^{1}$, Zhi-Zhou Shi ${ }^{1}$, Zhi-Xin Zhao ${ }^{2}$, Yu Zhang ${ }^{1}$, Ting Gong ${ }^{3}$, Chun-Xiang Li ${ }^{3}$, Ting Zhan ${ }^{1}$, Yan Cai ${ }^{1}$, Jin-Tang Dong ${ }^{4}$, Song-Bin Fu ${ }^{3}$, Qi-Min Zhan ${ }^{1}$ and Ming-Rong Wang ${ }^{1 *}$

\begin{abstract}
Background: Chromosomal and genomic aberrations are common features of human cancers. However, chromosomal numerical and structural aberrations, breakpoints and disrupted genes have yet to be identified in esophageal squamous cell carcinoma (ESCC).

Methods: Using multiplex-fluorescence in situ hybridization (M-FISH) and oligo array-based comparative hybridization (array-CGH), we identified aberrations and breakpoints in six ESCC cell lines. Furthermore, we detected recurrent breakpoints in primary tumors by dual-color FISH.

Results: M-FISH and array-CGH results revealed complex numerical and structural aberrations. Frequent gains occurred at 3q26.33-qter, 5p14.1-p11, 7pter-p12.3, 8q24.13-q24.21, 9q31.1-qter, 11p13-p11, 11q11-q13.4, 17q23.3-qter, 18pter-p11, 19 and 20q13.32-qter. Losses were frequent at 18q21.1-qter. Breakpoints that clustered within 1 or $2 \mathrm{Mb}$ were identified, including 9p21.3, 11q13.3-q13.4, 15q25.3 and 3q28. By dual-color FISH, we observed that several recurrent breakpoint regions in cell lines were also present in ESCC tumors. In particular, breakpoints clustered at 11q13.3-q13.4 were identified in 43.3\% (58/134) of ESCC tumors. Both 11q13.3-q13.4 splitting and amplification were significantly correlated with lymph node metastasis (LNM) $(P=0.004$ and 0.022$)$ and advanced stages $(P=0.004$ and 0.039 ). Multivariate logistic regression analysis revealed that only 11q13.3-q13.4 splitting was an independent predictor for LNM $(P=0.026)$.
\end{abstract}

Conclusions: The combination of M-FISH and array-CGH helps produce more accurate karyotypes. Our data provide significant, detailed information for appropriate uses of these ESCC cell lines for cytogenetic and molecular biological studies. The aberrations and breakpoints detected in both the cell lines and primary tumors will contribute to identify affected genes involved in the development and progression of ESCC.

\footnotetext{
* Correspondence: wangmr2015@cicams.ac.cn

'State Key Laboratory of Molecular Oncology, Cancer Institute (Hospital), Peking Union Medical College and Chinese Academy of Medical Science, 17 Panjiayuan Nanli, Chaoyang District, Beijing 100021, China

Full list of author information is available at the end of the article
} 


\section{Background}

Chromosomal and genomic rearrangements are significant features of malignant human tumors. Rearrangements are often associated with structural aberrations, such as translocations, insertions and inversions. They could also result in the copy number alterations (CNAs) $[1,2]$. Characterizing rearrangements and genes affected by the aberrations and breakpoints might help us to understand tumor development and progression better.

The products and implications of chromosomal rearrangements (e.g., fusion genes, truncated genes, and gene dysregulation by ectopic promoters) have been described in leukemia, lymphoma, sarcomas, and epithelial cancers [3,4]. It was initially difficult to detect chromosomal rearrangements and affected genes in the epithelial cancers, mainly due to the technical difficulty of preparing metaphase spreads from primary epithelial tumors and the karyotypic complexity. Until recently, multiple gene rearrangements and even genomic landscapes which reflect the structural aberrations throughout the genomes have been identified in multiple types of epithelial cancers, including prostate cancer $[5,6]$, breast cancer $[7,8]$, lung cancer $[9,10]$, colorectal cancer [11], gastric cancer [12], head and neck cancer [13], hepatocellular carcinoma [14] and so on.

Recently, it has been reported that recurrent rearrangements could affect genes at the boundaries of CNAs $[2,15]$, thus recurrent breakpoints might be important for screening and identifying frequent unbalanced rearrangements and the involved genes. Multiplex-fluorescence in situ hybridization (M-FISH) [16] and spectral karyotyping (SKY) [17] were designed to replace traditional Gbanding in chromosomal analyses of tumor cells, but the resolution of these techniques is not sufficient to detect small rearrangements. Array-based comparative genomic hybridization (array-CGH) was developed to analyze the CNAs, including genomic gains, losses, amplifications and deletions $[18,19]$. It was recently demonstrated that array-CGH could be used to identify unbalanced breakpoints of the rearrangements in many types of cancer cells at a potentially higher resolution [20-24]. Array$\mathrm{CGH}$ has also been used, in combination with cytogenetic information, to determine the breakpoints in reciprocal translocations [25].

Esophageal cancer $(E C)$ is a common malignant epithelial cancer worldwide, causing more than 40,000 deaths each year [26]. The most prevalent type of EC is esophageal squamous cell carcinoma (ESCC), and China is among the highest risk areas [26,27]. Recently, our group reported the karyotype of ESCC cell line KYSE180 [28] and KYSE450 [29] by 12-color M-FISH, as well as the karyotype of KYSE410-4 by 6-color M-FISH [30]. CGH [31-34], SKY and CGH [35], and array-CGH [36-38] experiments from other groups have also been performed on ESCC cell lines and primary tumors. These studies have revealed numerical and structural chromosomal aberrations. However, genomic rearrangements, breakpoints and genes that are involved in ESCC remain to be decoded and clarified.

Our study intended to identify candidate recurrent breakpoints which might affect genes at or near the boundaries. In this study, we describe CNAs and unbalanced genetic rearrangements in six ESCC cell lines through a combination of M-FISH and 44K array-CGH techniques. We found recurrent breakpoint regions in the cell lines and breakage of several regions present in primary ESCC tumors, which may contribute to disruption of critical genes.

\section{Methods}

\section{Cell lines and sample collection}

ESCC cell lines KYSE30, KYSE150, KYSE180, KYSE450, KYSE510 and YES2 were kindly provided by Yutaka Shimada (Kyoto University, Japan). KYSE150 and KYSE510 were established from female patients, and KYSE30, KYSE180, KYSE450 and YES2 were from male patients. Each cell line was cultured in RPMI-1640 (Invitrogen, USA) supplemented with $10 \%$ fetal calf serum (FCS). ESCC tissue samples were procured from Chinese Academy of Medical Sciences Cancer Hospital. All the samples used in this study were residual specimens collected after diagnosis sampling. And all patients received no treatment before surgery, and signed separate informed consent forms for the sampling and molecular analyses. This study has been approved by the Ethics Committee/ IRB of Cancer Institute (Hospital), PUMC/CAMS.

\section{Metaphase chromosomes and interphase cell nuclei preparations}

Metaphase chromosomes from ESCC cell lines and normal peripheral blood lymphocytes were harvested after incubation with $0.04 \mu \mathrm{g} / \mathrm{ml}$ Colcemid (Invitrogen) at $37^{\circ} \mathrm{C}$ for 1-2 hours, followed by treatment with a hypotonic solution $(0.075 \mathrm{~mol} / \mathrm{L} \mathrm{KCl})$ for 30 minutes and three successive changes of the fixative solution (methanol/acetic acid, 3:1). ESCC tissue samples were cut into small pieces in phosphate-buffered saline (PBS), and the interphase nuclei were then prepared following the procedures described above. Metaphase chromosomes and interphase cell nuclei in suspensions were stored at $4^{\circ} \mathrm{C}$ overnight and then stored at $-20^{\circ} \mathrm{C}$ until use. The nuclear suspensions were dropped onto clean slides and aged at room temperature for 2-3 days prior to the FISH experiments.

\section{Fluorescence in situ hybridization (FISH)}

M-FISH was performed on the metaphase spreads. The 24color whole chromosome painting (WCP) and arm-specific probes were directly labeled with diethylaminocoumarin 
(DEAC)-dUTP (PerkinElmer Inc., USA), Green-dUTP (Abbott Molecular, USA), Cy3-dUTP (GE Healthcare, USA) or Alexa594-dUTP (Invitrogen) by degenerate oligonucleotide primed-polymerase chain reaction (DOP-PCR) [39] or were indirectly labeled with Biotin11-dCTP (Invitrogen). Biotin was then visualized with streptavidin-conjugated Cy5 (Jackson Immunoresearch Laboratories Inc., USA). The 12-color FISH probes were labeled with Green-dUTP, Cy3-dUTP, Alexa594dUTP and Cy5-dUTP.

Split regions were detected using dual-color breakapart bacterial artificial chromosome (BAC) DNA clone probes, which were labeled with Green-dUTP and Cy3dUTP by random priming using BioPrime DNA labeling system (Invitrogen). BAC DNA clones were selected according to their descriptions in Ensembl database (www.ensembl.org). BAC DNA clones used to detect splitting of 11q13.3-q13.4 and associated regions included NONSC16D6 (68,072,319-68,278,585, hg18), Cancer_1D11 (69,162,501-69,323,924, hg18), NONSC2E5 (70,236,623-70,391,405, hg18), NONSC3C5 (71,992,71572,182,751, hg18) and NONSC15F5 (75,107,934-75,273,492, hg18).

The slides for M-FISH and dual-color break-apart FISH analyses were pretreated with RNase A (100 mg/ $\mathrm{ml}$ in $2 \mathrm{x}$ saline sodium citrate $[\mathrm{SSC}])$ and pepsin (50 $\mathrm{mg} / \mathrm{ml}$ in $0.01 \mathrm{~mol} / \mathrm{l} \mathrm{HCl}$ ). The slides were subsequently denatured in $70 \%$ formamide $/ 2 \times \mathrm{SSC}$ at $73^{\circ} \mathrm{C}-75^{\circ} \mathrm{C}$ for 3 minutes, quickly cooled with two rinses of $2 \times \mathrm{SSC}$ at $4{ }^{\circ} \mathrm{C}$, dehydrated in a gradient series of ethanol $(75 \%, 85 \%$ and $100 \%)$, and air dried. The labeled probes were precipitated, and redissolved in the hybridization solution (50\% formamide, $10 \%$ dextran sulfate, 1\% Tween-20, $2 \times$ SSC), denatured at $75^{\circ} \mathrm{C}$ for 8 minutes, and quick-chilled on ice for 2 minutes. Hybridization was performed in a humid chamber at $37^{\circ} \mathrm{C}$ for $24-48$ hours. Posthybridization washes were performed in $50 \%$ formamide/ $2 \times \mathrm{SSC}$ for 15 minutes at $43^{\circ} \mathrm{C}$ and were performed twice for 3 minutes each in $2 \times$ SSC. The slides were dehydrated in $75 \%, 85 \%$ and $100 \%$ ethanol, air dried, counterstained with 40,6-diamidino-2-phenylindole (DAPI) $(1 \mathrm{mg} / \mathrm{ml})$ and covered with coverslips.

For 12-color FISH analysis [28], the slides were hybridized twice on metaphase spreads as previously described, which was named two-round FISH. After digital fluorescence image acquisition, coverslips on the slides were removed by dipping in $100 \%$ ethanol for 30 min, and washed twice in 100\% ethanol for 3 min each time, then air dried, and then the slides could be denatured as the above procedures.

\section{Microscopy and digital image analysis}

FISH images were captured using a Zeiss Axio fluorescence microscope equipped with a cooled charged- coupled device (CCD) camera (Princeton Instruments, USA) or a JAI M4 Plus CCD camera (Metasystems International, Germany). All of the fluorescent images were captured with individual single-band-pass filters specific for visualizing DAPI, DEAC, Green, Cy3, Alexa 594 and Cy5 fluorochromes. Pseudo-color images were constructed and analyzed using MetaMorph (Universal Imaging Corporation, USA) or Metacyte module of Metafer imaging systems (Metasystems International).

\section{Genomic DNA isolation and oligo array-based comparative genomic hybridization (array-CGH)}

Genomic DNA from ESCC cell lines was isolated using DNeasy Blood \& Tissue Kit (Qiagen, Germany). Genome-wide copy number studies were then performed using an Agilent 44K oligo array platform (Agilent Technologies, USA), with sex-matched normal human DNA (Promega Corporation, USA) used as the reference. Briefly, $1 \mu \mathrm{g}$ samples of the tested and reference DNA were digested with AluI and RsaI, and differentially labeled with Cy3-dUTP and Cy5-dUTP using Agilent Genomic DNA Enzymatic Labeling Kit Part Number 5190-0449 (Agilent Technologies), respectively. Then Microcon YM-30 (Millipore) was used to clean up the labeled probes. Tested and reference DNA probes were combined and hybridized onto the microarrays enclosed in Agilent SureHyb-enabled hybridization chambers for 40 hours. After hybridization, slides were washed sequentially and scanned with an Agilent DNA Microarray Scanner. Annotations for the probes were based on UCSC hg18 (NCBI Build 36). CNAs and breakpoint data were analyzed via the Agilent Genomic Workbench Software 5.0, set to use the ADM-2 algorithm, an aberration threshold of 5.0 and an absolute average $\log _{2}$ ratio $\geq 0.5$.

\section{Statistical analysis}

Statistical analyses were carried out by using the SPSS 17.0 software package. The association between splitting of breakpoint regions and clinico-pathological characteristics were assessed by the $\chi^{2}$ test, Fisher's exact test or Kruskal-Wallis test. Logistic regression analysis was performed to determine the independent predictors of lymph node metastasis. $P$ values $<0.05$ were considered significant.

\section{Results}

\section{Copy number alterations}

M-FISH was performed on the metaphase chromosomes of four ESCC cell lines (KYSE30, KYSE150, KYSE510 and YES2). Modal karyotypes of the cell lines are shown in Figure 1. M-FISH karyotypes of two other cell lines KYSE180 [28] and KYSE450 [29] have been previously reported by our laboratory. We found multiple 


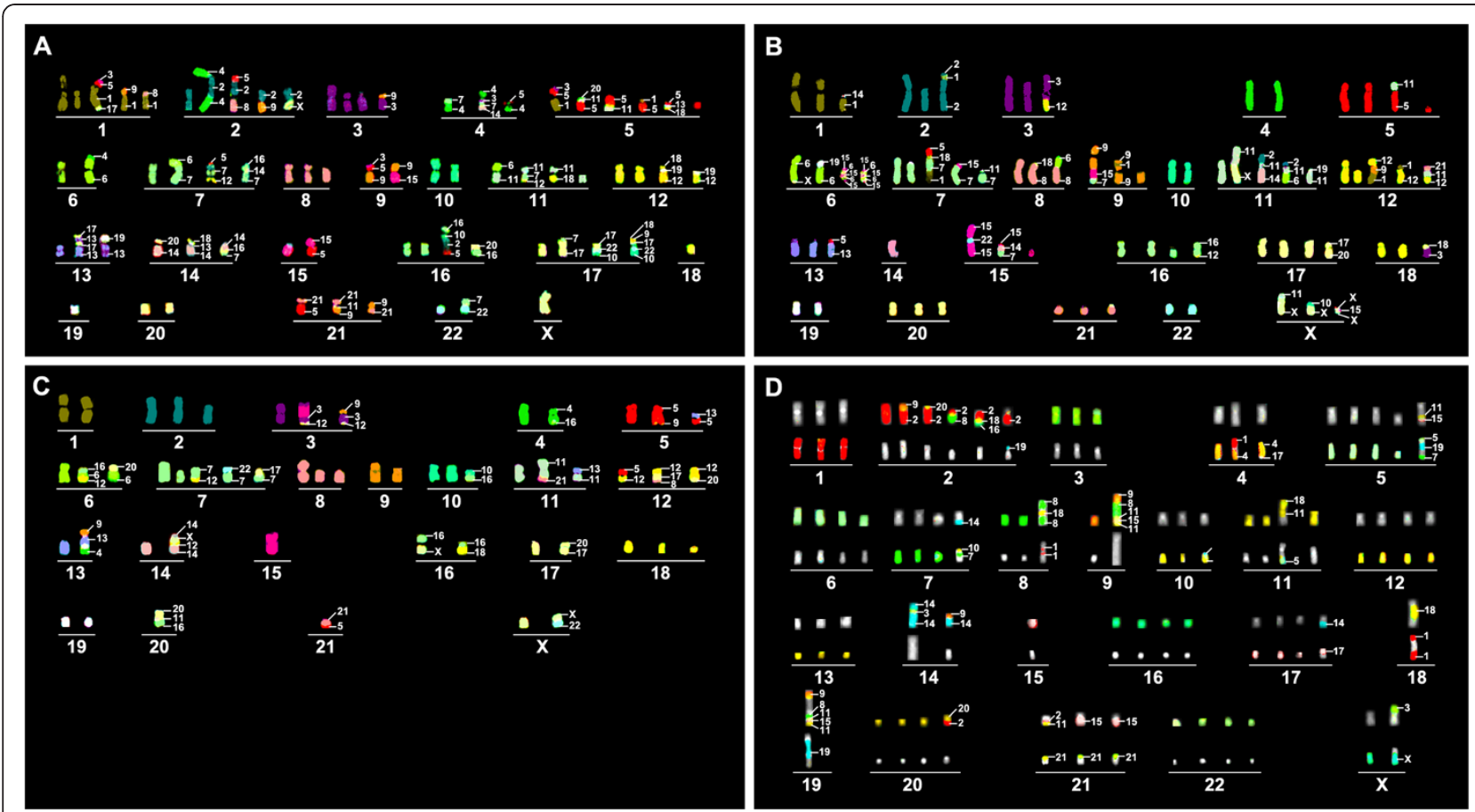

Figure 1 M-FISH profiling of ESCC cell lines. A 24-color analysis technique was used for KYSE30 (A), KYSE150 (B), and YES2 cells (C) and 12color detection was used for KYSE510 cells (D)

numerical alterations in the six cell line, which exhibited high level of aneuploidy. An overview of CNAs indicated that imbalances occurred throughout the entire genome of the cell lines. Gains were observed at $1 p, 1 q, 3 p, 3 q$, $4 \mathrm{p}, 5 \mathrm{q}, 7 \mathrm{p}, 8 \mathrm{q}, 9 \mathrm{q}, 11 \mathrm{q}, 14 \mathrm{q}, 16 \mathrm{p}, 16 \mathrm{q}, 17 \mathrm{p}, 17 \mathrm{q}, 18 \mathrm{p}$, $19 p, 19 q, 20 q$, and $22 q$. Losses were primarily detected at $3 \mathrm{p}, 4 \mathrm{p}, 4 \mathrm{q}, 6 \mathrm{p}, 6 \mathrm{q}, 9 \mathrm{p}$, and $18 \mathrm{q}$.

The detail CNAs of these cell lines were detected by array-CGH, and the profiles of gains and losses are shown in Figure 2 and Additional file 1: Table S1. Our results were compared with the data available from Cancer Cell Line Project on the Wellcome Trust Sanger Institute Cosmic website (http://www.sanger.ac.uk/ genetics/CGP/cosmic). Copy number data of KYSE150, KYSE450 and KYSE510 on the website were analyzed using Affymetrix SNP6.0 arrays. Copy number profiles derived from our Agilent $44 \mathrm{~K}$ platform are very similar to those from the Affymetrix platform. We then compared CNAs among the six cell lines according to the array-CGH data, and frequent gains and losses in at least two cell lines were summarized in Table 1. More gains were found than losses. The results were combined with the data from other 17 ESCC cell lines available on Cosmic website, including KYSE70, KYSE140, KYSE270, KYSE410, KYSE520, Colo-68N, EC-GI-10, HCE-4, TE-1, TE-5, TE-6, TE-8, TE-9, TE10, TE-11, TE-12 and TE-15. The gains with high frequencies were shown in Additional file 2: Table S2.
Regions with average $\log _{2}$ ratio values greater than 1 were defined as amplifications. High-level amplifications (HLAs) and homozygous deletions (HDs) were identified if the absolute average values were no less than 2 . According to the positions of HLAs and HDs boundaries, the smallest HLA and HD regions and involved genes among these cell lines were listed in Table 2 . HLAs include $7 \mathrm{p} 11$ (2/6, 33\%), 8q24.21 (2/6,33\%) and 11q13.3-q13.4 (3/6, 50\%), harboring several oncogenes, including EGFR, MYC and CTTN (Table 2). Homozygous deletion of $9 \mathrm{p} 21.3$, containing tumor suppressor genes $C D K N 2 A, C D K N 2 B$ and $C D K N 2 B-A S 1$, occurred in $67 \%(4 / 6)$ of the cell lines.

\section{Unbalanced breakpoints}

Breakpoints were restricted to the boundaries between two adjacent DNA fragments with significantly distinctive $\log _{2}$ ratio values, reflecting different copy numbers. Using this scheme, 261 candidate unbalanced breakpoints were identified (Additional file 3: Table S3). Among these candidates, 39 occurred in the centromeric regions, and the other 224 were present on chromosome arms. Fifty-seven of arm breakpoints were localized in the vicinity of fragile sites. Breakpoints on chromosome arms and copy number status of the regions at both sides of the breakpoints were listed in Additional file 3: Table S3. Cell lines were ranked according to the number of breakpoints, and the top three were KYSE30, 


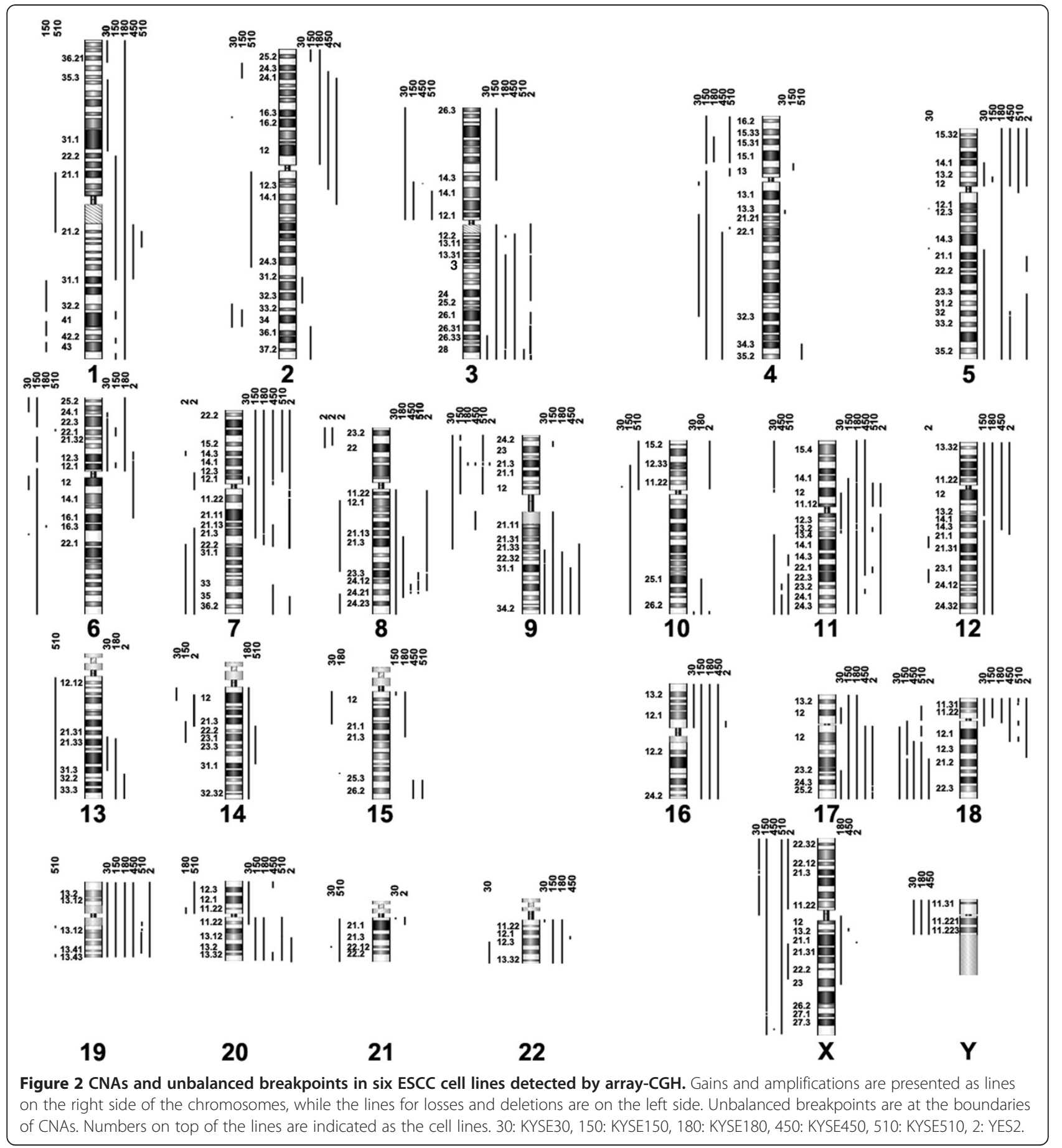

KYSE510 and YES2, respectively. This tendency was similar to that in M-FISH results.

\section{Chromosomal structural aberrations}

M-FISH results of four cell lines (KYSE30, KYSE150, KYSE510 and YES2) as well as that of the previously reported two cell lines (KYSE180 and KYSE450) showed that a total of 156 derivative chromosomes resulted from translocations, most of which were unbalanced; only $12.8 \%$ (20/156) were reciprocal. Approximately, 35\% of the translocation derivative chromosomes were fused at the centromeric regions. Chromosomes 1, 2, 3, 5, 6, 7, 8, $9,11,12,14,15$ and $\mathrm{X}$ were frequently rearranged. Combining M-FISH with array-CGH, we further characterized multiple rearrangements present in these cell lines (Table 3). KYSE30 is the cell line with the most complex 


\begin{tabular}{|c|c|c|}
\hline CNAs & $\begin{array}{c}\text { Positive } \\
\text { No. of cell lines }\end{array}$ & Region \\
\hline \multirow[t]{3}{*}{ Gain } & $\geq 5$ & $\begin{array}{l}\text { 3q26.33-qter, 5p14.1-p11, 7pter-p12.3, } \\
\text { 8q24.13-q24.21, 9q31.1-qter, 11p13-p11, } \\
11 \text { q11-q13.4, 17q23.3-qter, 18pter-p11, } \\
\text { 19, 20q13.32-qter }\end{array}$ \\
\hline & $3-4$ & $\begin{array}{l}\text { 1q21.1-q31.1, 2p24.1-p11, 3q13.31-q26.33, } \\
\text { 5pter-p11, 5q31.1-qter, 5q32-qter, 6p21.1-p11, } \\
\text { 6p21.31-p11, 7pter-p12.3, 7q11-q22.2, } \\
\text { 8q21.2-q24.21, 8q23.3-q24.21, 9q22.1-qter, } \\
\text { 10q26.3-qter, 11q11-q22.3, 11q13.4-qter, } \\
\text { 12pter-p14.4, 16pter-p11, 16q11-qter, } \\
\text { 17p13.1-p11, 17q, 20q11-qter, 20q13.12-qter }\end{array}$ \\
\hline & 2 & $\begin{array}{l}\text { 1pter-p36.13, 1p35.2-q31.1, 1p22.2-q31.1, } \\
\text { 2pter-p25.1, 2p24.2-p11, 2q11-q13, 3q12.1-qter, } \\
\text { 5q15-qter, 6p21.33-p21.1, 7q35-qter, } \\
\text { 8q11-q24.21, 9q21.33-qter, 11pter-p14.1, } \\
\text { 12q14.4-qter, 13q21.32-q31.3, 13q32.1-qter, } \\
\text { 14q22.1-q31.1, 15q11, 15q25.3-qter, } \\
\text { 16q11-qter, 17pter-p11, 18q11-q12.2, 22q }\end{array}$ \\
\hline \multirow[t]{3}{*}{ Loss } & $\geq 5$ & 18q21.1-qter \\
\hline & $3-4$ & $\begin{array}{l}\text { 3p14.1-p11, 4p15.32-p14, 4q22.1-q32.3, } \\
\text { 9pter-p24.1, 9p23-p11, 11q23.3-qter, } \\
\text { 18q12.2-q21.1, Xpter-p11, Xq21.1-q23 }\end{array}$ \\
\hline & 2 & $\begin{array}{l}\text { 2q33.1-q35, 3p14.2-p14.1, 4pter-p14.1, } \\
\text { 4q21.1-q32.3, 4q22.1-qter, 6pter-p24.1, } \\
\text { 6q11-q13, 7q22.2-qter, 8pter-p22, } \\
\text { 9pter-p11, 9q11-q21.13, 10p12.33-p11, } \\
\text { 11q24.1-qter, 11q22.3-qter, Xq11-qter, }\end{array}$ \\
\hline
\end{tabular}

rearrangements, and array-CGH results have also indicated that much more breakpoints were present in KYSE30 than the other cell lines, which are consistent with M-FISH results.

\section{Recurrent breakpoint regions in ESCC cell lines and primary tumor tissues}

Positions of the breakpoints were compared among different cell lines, and further the distances of near breakpoint regions were calculated. Five regions (11q13.4, 9p21.3, 15q25.3, 3q28 and 10q26.3) had breakpoints less than $1 \mathrm{Mb}$ apart, and twelve (11q13.3, 4p13, 11p13, 8q24.21, 2q35, 1q31.1, 21q21.1, 9p21.3, 18q12.2, 3p14.2, 3q12.1-q12.2 and 6p12.3-p12.2) had breakpoints less than $2 \mathrm{Mb}$ apart in different cell lines (Table 4). For example, breakpoints at 11q13.4 were detected in KYSE30 and KYSE510, while breakpoints at 11q13.3 were detected in KYSE30 and KYSE180 (Figure 3A). The three cell lines presented gain of $11 \mathrm{q}$ and amplification of 11q13, in which copy numbers of the regions flanking centromere to $11 \mathrm{q} 13$ amplicon was higher than the region distal to the amplicon. Losses of the region distal to $11 \mathrm{q} 13$ were also found as del(11q13.4-qter) in KYSE30, $\operatorname{del}(11 \mathrm{q} 14.3-\mathrm{q} 21)$ and del(11q22.3-qter) in KYSE510. Translocations of highly amplified regions were also observed (Table 3).

Genes which might be interrupted by the recurrent breakpoints in each cell line were listed in Table 4. Ten of these common breakpoint regions were localized in the vicinity of fragile sites. Genes in these cell lines with inner breakpoints included CDKN2A, LEPREL1, JAKMIP3, LIMCH1, CSTF3, ABTB2, CDKN2B-AS1, FHIT and $A B I 3 B P$. For these genes, one breakpoint could be detected. Small HDs were also observed inside some genes, resulting in two breakpoints, such as FHIT gene in KYSE450. Other genes flanking or close to the boundaries might also be influenced by the breakpoints.

To determine whether genomic aberrations found in these cell lines are also present in primary tumors, we first tested a small sample of 15 ESCC tumors by dualcolor FISH. This analysis revealed splitting of regions 11q13.3-q13.4, 9p21, 15q25.3 and 3q28, which presented the highest frequency of disruption in the cell lines. Splitting of these regions had occurred in 5, 1, 2 and 3 out of 15 tumors, respectively. We also examined online data of ESCC cell lines. The results showed that both high level amplifications and breakages existed at 67-72 $\mathrm{Mb}$ positions in 11q13 (Figure 3). Multiple breakpoints

Table 2 High level amplifications and homozygous deletions in different cell lines

\begin{tabular}{|c|c|c|c|c|c|}
\hline CNAs & Region $^{a}$ & Cell line & Start & Stop & Genes \\
\hline \multirow[t]{3}{*}{ HLA } & $7 p 11$ & KYSE30, KYSE450 & 54572103 & 57613746 & $\begin{array}{l}\text { VSTM2A, SEC61G, EGFR, LANCL2, } \\
\text { VOPP1, FKBP9L, ZNF713, MRPS17, } \\
\text { GBAS, PSPH, CCT6A, SUMF2, PHKG1, } \\
\text { CHCHD2, ZNF479, ZNF716 }\end{array}$ \\
\hline & $8 q 24.21$ & KYSE450, KYSE510 & 128548643 & 129216964 & POU5F1B, LOC727677, MYC, PVT1 \\
\hline & $11 q 13.3-q 13.4$ & KYSE30, KYSE180, KYSE510 & 68232360 & 70964483 & $\begin{array}{l}\text { MTL5, CPT1A, MRPL21, IGHMBP2, } \\
\text { MRGPRD, MRGPRT, TPCN2, MYEOV, } \\
\text { CCND1, ORAOV1, FGF19, FGF4, } \\
\text { FGF3, ANO1, FADD, PPFIA1, } \\
\text { CTTN, SHANK2, DHCR7, NADSYN1, } \\
\text { KRTAP5-7, KRTAP5-8, KRTAP5-9, } \\
\text { KRTAP5-10, KRTAP5-11 }\end{array}$ \\
\hline $\mathrm{HD}$ & $9 p 21.3$ & KYSE180, KYSE450, KYSE510, YES2 & 21958099 & 22136626 & CDKN2A, CDKN2B, CDKN2B-AS1 \\
\hline
\end{tabular}


Table 3 Chromosomal structural aberrations analyzed by a combination of M-FISH and array-CGH

\begin{tabular}{|c|c|}
\hline Cell line & Chromosomal structural aberrations \\
\hline KYSE30 & 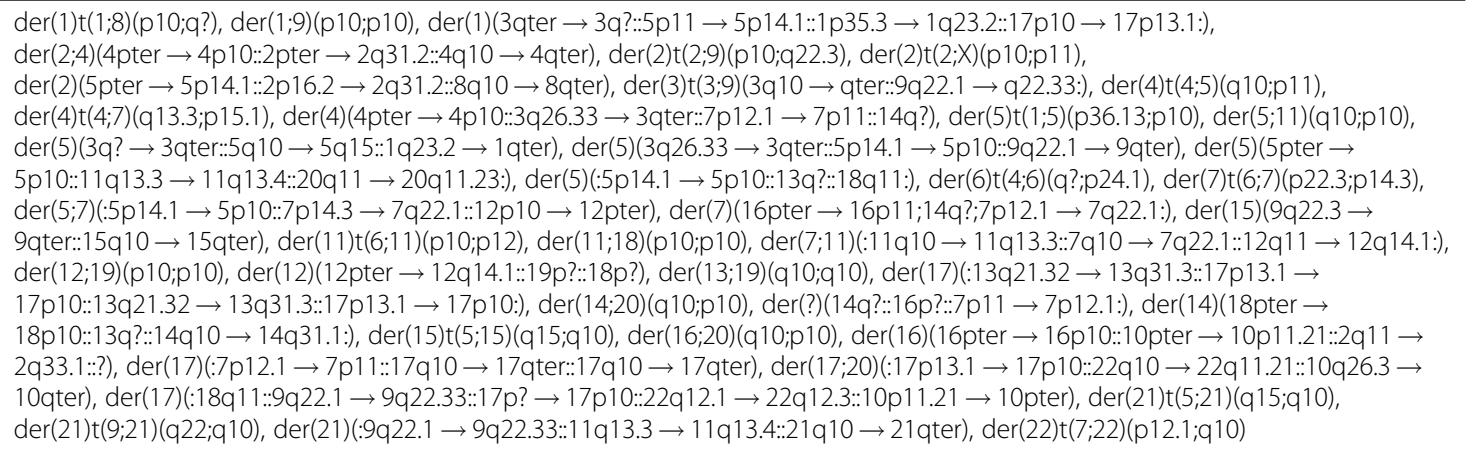 \\
\hline KYSE150 & 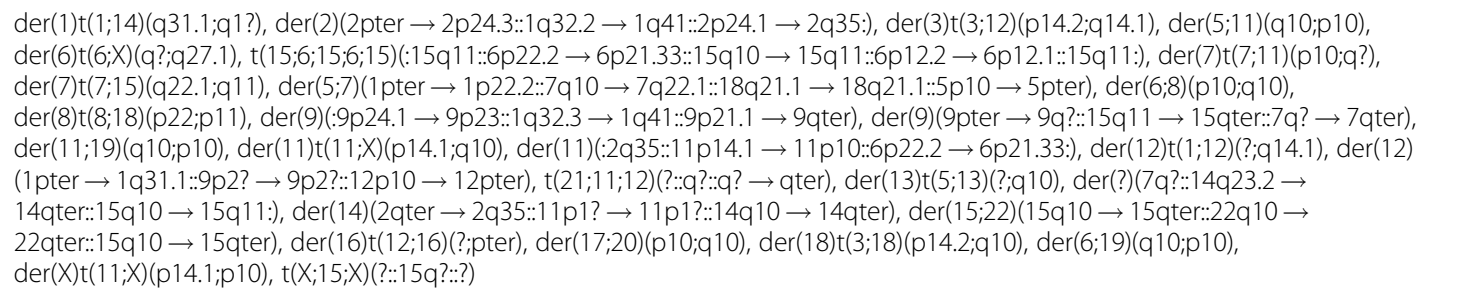 \\
\hline KYSE510 & 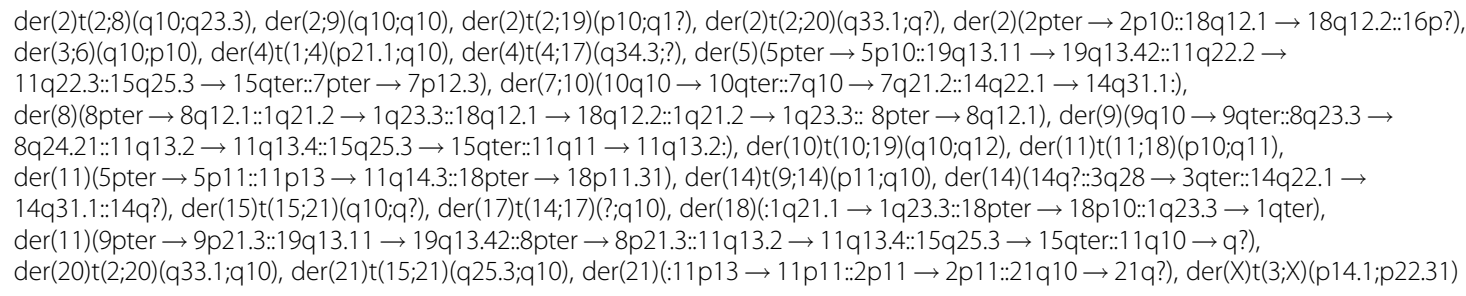 \\
\hline YES2 & 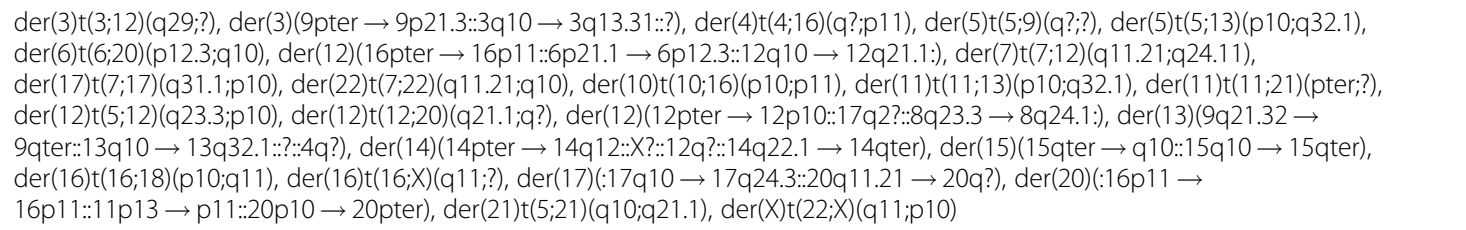 \\
\hline
\end{tabular}

are present in most of the cell lines, revealing these positions may be highly rearranged.

Due to the highest splitting frequency of 11q13.3q13.4 in the initial 15 cases, we further expanded the sample pool to further characterize splitting of this region in primary ESCC cases (Figures $3 \mathrm{~B}$ and $3 \mathrm{C}$ ). Splitting frequencies of $11 \mathrm{q} 13.4$ and $11 \mathrm{q} 13.3$ were $36.6 \%$ $(49 / 134)$ and $23.4 \%$ (32/137), respectively. Overall, breakage of 11q13.3-q13.4 was observed in 58 out of 134 cases (43.3\%). Next, we divided the whole 11q13.3q13.4 region into several parts, including 11q13.3(1) (CPT1A, MRPL21, IGHMBP2, MRGPRD, MRGPRF, TPCN2, MYEOV), 11q13.3(2) (CCND1, ORAOV1, FGF19, FGF4, FGF3, ANO1, FADD, PPFIA1, CTTN and SHANK2), 11q13.4(1) (DHCR7, NADSYN1, KRTAP5-7, KRTAP5-8, KRTAP5-9, KRTAP5-10, KRTAP5-11, FAM86C1, DEFB108B, RNF121, IL18BP, NUMA1, LRTOMT, FOLR3, FOLR1, FOLR2, INPPL1, PHOX2A and $C L P B)$. Regions of 11q13.3(1), 11q13.3(2), 11q13.4 (1), 11q13.3(2)-q13.4 and 11q13.3(2)-q13.4(1) were split in $16.3 \%(22 / 135), 8.4 \%(11 / 131), 24.1 \%(32 / 133), 41.0 \%$ $(55 / 134)$ and $30.0 \%(39 / 130)$ of the primary ESCC tumors, respectively. Almost all of the array-CGH images of the cell lines in Figure 3A and Additional file 4: Figure S1 showed amplification of the region proximal or distal to the breakpoints. Similarly, most of the splitting-positive ESCC tumors examined by FISH presented focal high-level amplification of the region. The majority of breakpoints between NONSC16D6 and Cancer_1D11 were proximal to the amplicon, while most of the breakpoints between Cancer_1D11 and NONSC2E5 as well as those between NONS2E5 and NONSC15F5 were distal to the amplicon (Figure 3C and Additional file 5: Table S4).

\section{Correlations between split and amplified regions and clinicopathological characteristics}

Clinicopathological parameters of each patient were listed in Additional file 6: Table S5, and the relationships 
Table 4 Recurrent breakpoint regions analyzed by array-CGH in ESCC cell lines

\begin{tabular}{|c|c|c|c|c|c|c|}
\hline Region & Cell line & $\mathrm{CN}_{\text {status }}{ }^{\mathrm{a}}$ & $\begin{array}{l}\text { BP Intervals (hg 18) } \\
\text { in array-CGH }\end{array}$ & $\begin{array}{l}\text { Distance } \\
\text { between } \\
\text { cell lines }\end{array}$ & Genes $^{c}$ & CFSs \\
\hline \multirow[t]{4}{*}{$9 p 21.3 a$} & KYSE180 & Neutral/Del & 21958099-21968346 & $115.1 \mathrm{~kb}$ & C9orf53 $3^{\S}, C_{K N N 2 A^{*}, C D K N 2 B}{ }^{\dagger}, C D K N 2 B-A S 1^{\dagger}$ & FRA9C \\
\hline & KYSE450 & Neutral/Del & 21853263-21968346 & & MTAP $\$$, C9orf53 $\$, C D K N 2 A *$ & \\
\hline & KYSE510 & Loss/Del & $21958099-21968346$ & & C9orf53 ${ }^{\S}, \mathrm{CDKN}_{2 A^{*}}{ }^{*}, \mathrm{CDKN} 2 \mathrm{~B}^{\dagger}, \mathrm{CDKN} 2 \mathrm{~B}-\mathrm{AS} 1^{+}$ & \\
\hline & YES2 & Neutral/Del & 21853263-21957548 & & MTAP $\$, C 90$ rf5 $3^{\dagger}, C D K N 2 A^{+}$ & \\
\hline \multirow[t]{2}{*}{$15 q 25.3$} & KYSE450 & Neutral/Gain & 86361096-86429254 & $154.2 \mathrm{~kb}$ & LINC00052 ${ }^{\S}$, NTRK $^{*}$, MRPL $6^{\dagger}$, MRPS $11^{\dagger}$ & \\
\hline & KYSE510 & Neutral/Gain & $86275066-86429254$ & & LINC00052 ${ }^{\S}$, NTRK $^{*}$, MRPL46 ${ }^{\dagger}$, MRPS $11^{\dagger}$ & \\
\hline \multirow[t]{2}{*}{$11 \mathrm{q} 13.4$} & KYSE30 & Amp/Loss & $70964483-71305189$ & $340.1 \mathrm{~kb}$ & KRTAP5-11 \$, FAM86C1, DEFB108B, RNF121 ${ }^{\dagger}$ & FRA11H \\
\hline & KYSE510 & Amp/Neutral & $70964483-71305189$ & & KRTAP5-11 $\$$, FAM86C1, DEFB108B, RNF121 ${ }^{\dagger}$ & \\
\hline \multirow[t]{2}{*}{$3 q 28$} & KYSE180 & Gain/Gain & $191171376-191222891$ & $517.0 \mathrm{~kb}$ & TP63 ${ }^{\S}$, LEPREL $^{*}$, CLDN1 ${ }^{\dagger}$ & \\
\hline & KYSE510 & Neutral/Gain & $191610761-191688399$ & & CLDN1 ${ }^{\S}, C L D N 16$, TMEM $07^{\dagger}, \operatorname{ILIRAP^{\dagger }}$ & \\
\hline \multirow[t]{2}{*}{$10 q 26.3$} & KYSE30 & Neutral/Gain & $133045086-133476780$ & $801.8 \mathrm{~kb}$ & TCERG1L ${ }^{\S}, P P P 2 R 2 D^{+}$ & \\
\hline & YES2 & Neutral/Gain & 133795639-133846905 & & BNIP3 ${ }^{\S}, J A K M I P 3^{*}$, DPYSL4 ${ }^{+}$ & \\
\hline \multirow[t]{2}{*}{$11 \mathrm{q} 13.3$} & KYSE30 & Amp/Amp & $69339391-69569221$ & $1.05 \mathrm{Mb}$ & FGF3 ${ }^{\S}$, ANO1 $^{\dagger}$, FADD $^{\dagger}$ & FRA11H \\
\hline & KYSE180 & Amp/Amp & $70182767-70386856$ & & CTTN ${ }^{\S}$, SHANK2 $^{*}$, DHCR7 $^{\dagger}$ & \\
\hline \multirow[t]{2}{*}{$4 p 13$} & KYSE150 & Amp/Loss & $41832777-42109513$ & $1.15 \mathrm{Mb}$ & SLC3OA9 $\$, B E N D 4$, SHISA3 ${ }^{\dagger}$, ATP8A $1^{\dagger}$ & \\
\hline & KYSE510 & Neutral/Loss & $40955943-41226036$ & & UCHL1 $1^{\S}, \mathrm{LIMCH} 1^{*}, \mathrm{PHOX} 2 \mathrm{~B}^{+}$ & \\
\hline \multirow[t]{2}{*}{$11 \mathrm{p} 13$} & KYSE510 & Neutral/Gain & $33107818-33136537$ & $1.2 \mathrm{Mb}$ & TCP11L1, PIGCP1 $\$$, CSTF3 $3^{*}$, HIPK3 ${ }^{+}$ & \\
\hline & YES2 & Neutral/Gain & $34278741-34307224$ & & NAT10 ${ }^{\S}, A B T B 2^{*}, C A T^{\dagger}$ & \\
\hline \multirow[t]{3}{*}{$8 q 24.21$} & KYSE450 & Amp/Neutral & $129216964-129574570$ & $1.23 \mathrm{Mb}$ & FAM84B $\$, P O U 5 F 1 B, M Y C^{\dagger}, P V T 1^{\dagger}$ & \\
\hline & KYSE510 & Amp/Loss & $129972316-130159085$ & & FAM84B $\$$, POU5F1B, MYC ${ }^{\dagger}$, PVT1 $^{\dagger}$ & \\
\hline & YES2 & Amp/Neutral & $130159144-130451718$ & & far from genes, $P V T 11^{\S}$, GSDMC $^{\dagger}$ & \\
\hline \multirow[t]{2}{*}{$2 q 35$} & KYSE30 & Loss/Neutral & $217432472-218386863$ & $1.37 \mathrm{Mb}$ & DIRC3 ${ }^{\S}, T N S 1, C X C R 2 P 1^{\dagger}$ & \\
\hline & KYSE150 & Loss/Gain & $218517852-218801703$ & & TNS1 ${ }^{\S}, C X C R 2 P 1, C X C R 2, C X C R 1, H M G B 1 P 9, A R P C 2^{\dagger}$ & \\
\hline \multirow[t]{2}{*}{$1 \mathrm{q} 31.1$} & KYSE150 & Gain/Loss & $186080345-186315797$ & $1.40 \mathrm{Mb}$ & 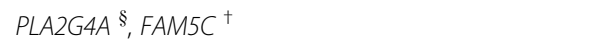 & FRATK \\
\hline & KYSE450 & Gain/Neutral & $184912220-185051701$ & & PTGS2 $\$$, PLA2G4A ${ }^{\dagger}$ & \\
\hline \multirow[t]{2}{*}{$21 q 21.1$} & KYSE30 & Gain/Neutral & $17060792-17145790$ & $1.48 \mathrm{Mb}$ & USP $25^{\S}$, C21orf $34^{\S}$, CXADR $^{\dagger}$ & \\
\hline & YES2 & Gain/Neutral & $18435266-18540695$ & & CHODL-AS1 $1^{\S}, \mathrm{CHODL}^{\dagger}, \mathrm{TMPRSS}_{15}{ }^{\dagger}$ & \\
\hline \multirow[t]{4}{*}{$9 p 21.3 b$} & KYSE180 & Del/Neutral & $21999029-22136626$ & $1.45 \mathrm{Mb}$ & CDKN2A ${ }^{*}$, CDKN2B, CDKN2B-AS1, DMRTA1 ${ }^{\dagger}$ & FRA9C \\
\hline & KYSE450 & Del/Neutral & $21980581-21993651$ & & CDKN2A ${ }^{*}, C D K N 2 B, C D K N 2 B-A S 1^{*}$, DMRTA1 $^{\dagger}$ & \\
\hline & KYSE510 & Del/Loss & $22992377-23425976$ & & DMRTA1 ${ }^{*}, E L A V L 2{ }^{\dagger}$ & \\
\hline & YES2 & Del/Neutral & $21999029-22136626$ & & CDKN2B, CDKN2B-AS1, DMRTA1 ${ }^{\dagger}$ & \\
\hline \multirow[t]{2}{*}{$18 q 12.2$} & KYSE450 & Gain/Loss & $33583906-33747373$ & $1.64 \mathrm{Mb}$ & CELF4 ${ }^{\S}$, LOC647946 $^{\dagger}$ & FRA18A \\
\hline & KYSE510 & Amp/Loss & $32107441-32200063$ & & MOCOS $\$, F H O D 3$, C18orf10 ${ }^{\dagger}$ & \\
\hline \multirow[t]{2}{*}{$3 p 14.2$} & KYSE150 & Gain/Loss & $58573676-58887412$ & $1.69 \mathrm{Mb}$ & FAM107A ${ }^{\S}$, FAM3D, C3orf67, FHIT $^{+}$ & FRA3B \\
\hline & KYSE450 & Neutral/Del & $59933661-60267262$ & & $F H I T^{\#}$ & \\
\hline \multirow[t]{2}{*}{$3 q 12.1-q 12.2$} & KYSE180 & Neutral/Amp & 100190484-100877203 & $1.86 \mathrm{Mb}$ & TFG ${ }^{\S}, A B I 3 B P^{*}, I M P G 2^{+}$ & \\
\hline & KYSE450 & Neutral/Gain & 102009730-102076392 & & DCBLD2 ${ }^{\S}, C O L 8 A 1^{\dagger}$ & \\
\hline \multirow[t]{2}{*}{$6 p 12.3-p 12.2$} & KYSE150 & Loss/Amp & 51932658-52161439 & $1.9 \mathrm{Mb}$ & PKHD1 $1^{\S}, I L 17 A^{\dagger}, M_{C M}{ }^{\dagger}$ & \\
\hline & YES2 & Gain/Gain & $50261630-50627364$ & & DEFB112 $2^{\S},{\text { TFAP } 2 D^{+}}^{+}$ & \\
\hline
\end{tabular}

a Copy number status on the left and right side of the breakpoint regions. CN: copy number, Amp: amplification, Del: deletion.

${ }^{b}$ The distance between two outermost breakpoints of all the different cell lines.

" These genes are located at or close to breakpoints in each cell line. " " right side of the breakpoint regions, respectively. Genes that are not labeled are located in the breakpoint regions, but positions of the exact breakpoints are not determined. "\#": Genes with an inside homozygous deletion (HD), and thus might also be disrupted. 


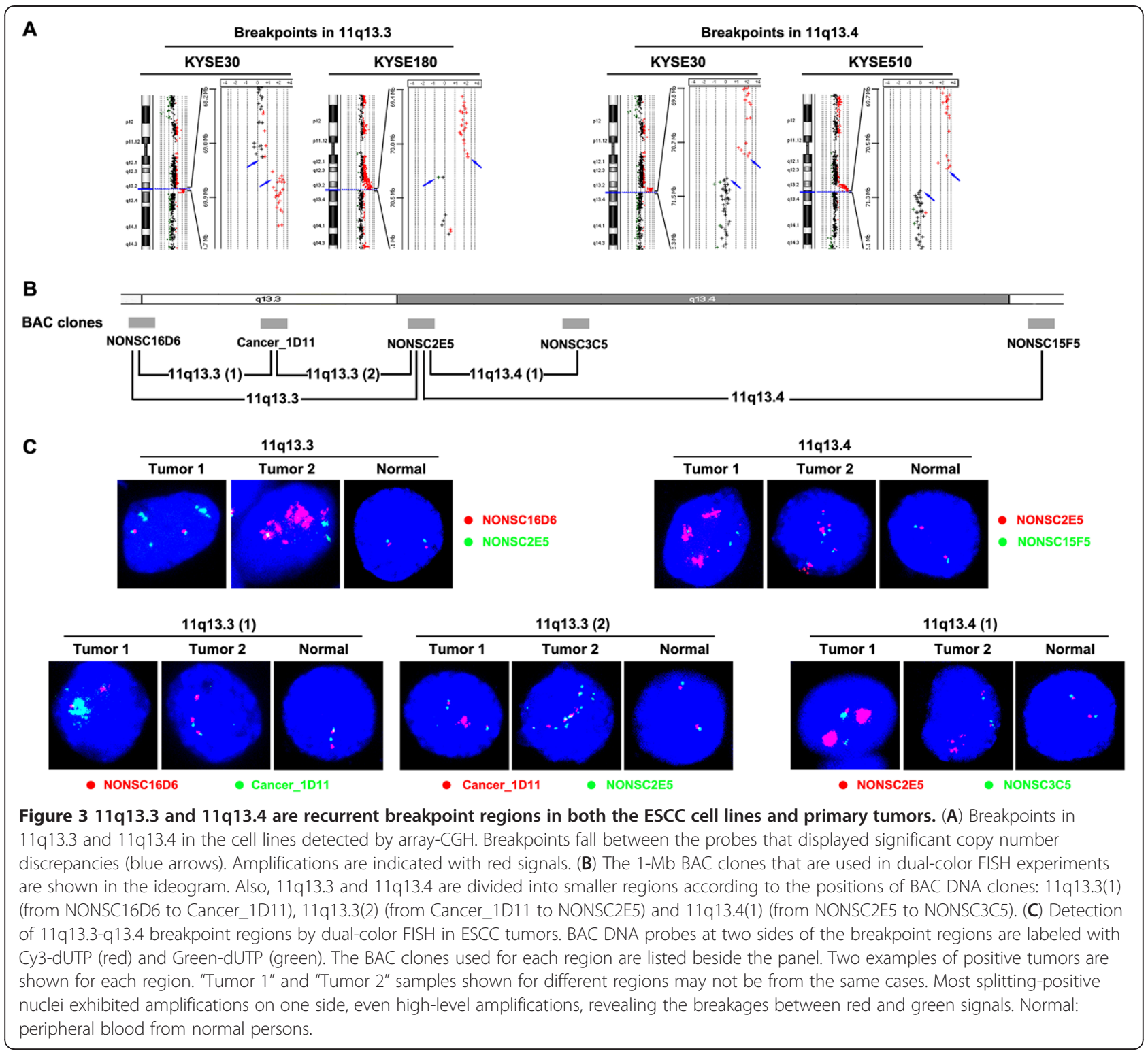

between regional splitting events and clinicopathological characteristics were summarized in Table 5. Splitting of 11q13.3-q13.4 was significantly correlated with lymph node metastasis $(\mathrm{LNM})(P=0.004)$ and advanced stages $(P=0.004)$. In LNM-positive group, $54.9 \%(39 / 71)$ of the tumors exhibited splitting compared with $30.2 \%(19 / 63)$ in LNM-negative group. Tumors at stages IIb/III/IV $(53.9 \%, 41 / 76)$ showed higher frequencies of splitting than those at stages I/IIa $(29.3 \%, 17 / 58)$. Breakpoint regions of 11q13.4, 11q13.4(1), 11q13.3(2)-q13.4(1) and 11q13.3(2)-q13.4 were also associated with LNM and advanced stages $(P<0.05$, Additional file 7: Table S6). No correlations were observed between splitting in these regions and other clinico-pathological parameters, including gender, age, tumor size, and differentiation (Table 5 and Additional file 7: Table S6). We also tested the relationship between amplification of this region and clinical features. 11q13.3-q13.4 amplifications were defined as the number of FISH signals was at least 3 (Additional file 5: Table S4). A positive correlation was observed between 11q13.3-q13.4 amplification and LNM $(P=0.022)$ or advanced stages $(P=0.039) \quad$ (Table 5$)$. Amplification of $11 \mathrm{q} 13.3$ or $11 \mathrm{q} 13.4$ alone was not associated with the parameters (Additional file 8: Table S7).

In order to create a multivariate model describing the risk for LNM, univariate and multivariate logistic regression analyses were performed with respect to gender, age, tumor size, differentiation status, as well as 11q13.3-q13.4 splitting and amplification. Multivariate analysis indicated that only splitting of 11q13.3-q13.4 was an independent predictor for LNM in ESCC $(P=0.026, \mathrm{RR}=2.357$, Table 6$)$. 
Table 5 Relationship between splitting and amplification of 11q13.3-q13.4 and clinical features of primary ESCC tumors

\begin{tabular}{|c|c|c|c|c|}
\hline \multirow[t]{2}{*}{ Clinical features } & \multicolumn{2}{|c|}{ Splitting } & \multicolumn{2}{|c|}{ Amplification } \\
\hline & Frequency & $P$ value & Frequency & $P$ value \\
\hline \multicolumn{5}{|l|}{ Gender } \\
\hline Male & $47.2 \%(50 / 106)$ & $0.089^{a}$ & $86.2 \%(94 / 109)$ & $1.000^{a}$ \\
\hline Female & $28.6 \%(8 / 28)$ & & $89.3 \%(25 / 28)$ & \\
\hline \multicolumn{5}{|l|}{ Age } \\
\hline$<60$ & $47.8 \%(33 / 69)$ & 0.274 & $87.1 \%(61 / 70)$ & $1.000^{a}$ \\
\hline$\geq 60$ & $38.5 \%(25 / 65)$ & & $86.6 \%(58 / 67)$ & \\
\hline \multicolumn{5}{|l|}{ Tumor size } \\
\hline $\mathrm{T} 1, \mathrm{~T} 2$ & $50.0 \%(10 / 20)$ & 0.511 & $85.0 \%(17 / 20)$ & $0.728^{a}$ \\
\hline $\mathrm{T} 3, \mathrm{~T} 4$ & $42.1 \%(48 / 114)$ & & $87.2 \%(102 / 117)$ & \\
\hline \multicolumn{5}{|c|}{ Lymph node metastasis } \\
\hline No & $30.2 \%(19 / 63)$ & 0.004 & $79.4 \%(50 / 63)$ & $0.022^{a}$ \\
\hline N1 & $54.9 \%(39 / 71)$ & & $93.2 \%(69 / 74)$ & \\
\hline \multicolumn{5}{|l|}{ Stage } \\
\hline I, Ila & $29.3 \%(17 / 58)$ & 0.004 & $79.3 \%(46 / 58)$ & $0.039^{a}$ \\
\hline$\| b, I I I, I V$ & $53.9 \%(41 / 76)$ & & $92.4 \%(73 / 79)$ & \\
\hline \multicolumn{5}{|l|}{ Differentiation } \\
\hline G1 & $40.7 \%(11 / 27)$ & $0.762^{b}$ & $85.2 \%(23 / 27)$ & $0.118^{b}$ \\
\hline $\mathrm{G} 2$ & $41.7 \%(30 / 72)$ & & $91.9 \%(68 / 74)$ & \\
\hline G3 & $48.6 \%(17 / 35)$ & & $77.8 \%(28 / 36)$ & \\
\hline
\end{tabular}

${ }^{a}$ Fisher's test.

${ }^{b}$ Kruskal-Wallis test.

The $P$ value which is not labeled with " $a$ " or " $b$ " is assessed by $x 2$ test.

\section{Discussion}

Genomic numerical and structural alterations are common features in ESCC. Our study characterized CNAs, structural aberrations, and recurrent breakpoints in six ESCC cell lines by a combination of M-FISH and arrayCGH analyses, which helps provide accurate karyotypes of these cell lines. We further found the correlation between splitting of an amplified region 11q13.3-q13.4 and lymph node metastasis.

Genomic CNAs may influence gene expression through the following mechanisms. A well known mechanism is that gains or losses may result in gene amplifications or deletions, and thus upregulate or downregulate the protein expression [40]. Different situations may occur on genes at the boundaries of gain or loss regions. CNA boundaries inside of the genes usually indicate gene breakage. Gene rearrangements may result from such breakages, leading to the formation of an aberrant gene product [41]. If the CNA boundaries occur in non-coding regions flanking genes, expression may be controlled by proximity to regulatory sequences from other genes. Alternatively, the recurrent breakpoint may indicate loss of a tumor suppressor gene distal to the CNA boundary [42]. Small deletions inside of the genes may result in structural aberrant proteins, truncated proteins, or even loss-of-function proteins. Small amplifications and deletions inside of genes may also indicate gene breakage, and the gene products may also be affected by rearrangements with the partner gene. On the other hand, many recurrent rearrangements occurred at boundaries of the breakpoints, resulting in fusion genes, truncated genes, as well as other structural variants [2]. Therefore, we focused on the breakpoints with CNAs involved in genomic rearrangements and breakpoints mapped to specific sites.

Copy number profiling of ESCC have been analyzed from different studies. Gains involved regions $5 p, 7 p, 7 q$, $8 \mathrm{q}, 11 \mathrm{q}, 12 \mathrm{p}, 14 \mathrm{q}, 16 \mathrm{p}, 19 \mathrm{q}, 20 \mathrm{q}$ and have been reported in ESCC cell lines by SKY and CGH [35], as well as at least $60 \%$ primary tumors by $32 \mathrm{~K}$ array-CGH [36]. Recently, gains of 19p13.3-q13.43, 11q13.1-q13.4, 20p13q13.33, 3q24-q29, 22q11.21-q12.1 have been reported [38]. We detected six cell lines, and compared with online database, the high frequency of gains mainly include 3q26.33-qter, 5p14.1-p11, 7pter-p12.3, 8q24.13-q24.21, 9q31.1-qter, 11p13-p11, 11q11-q13.4, 17q23.3-qter, 18pter-p11, 19p, 19q and 20q13.32-qter. Gain of $3 \mathrm{q}$ is prevalent in ESCC, and 3q26-qter was found in 76.5\% (39/51) primary tumors [43] and $66.7 \%(4 / 6)$ cell lines [44], suggesting cancer-related genes may be present in 3q26-qter. Evidence has been found that PIK3CA [35,45], PRKCI [46], and ZNF639 [47] are amplified and overexpressed in ESCC. PIK3CA [45] and PRKCI [46] are associated with LNM and overexpression of PIK3CA and TFRC are associated with poor prognosis [48]. We found gain of 5p14.1-p11 existed in 83.3\% (5/6) cell lines. In the previous study, gain of $5 \mathrm{p} 13$ was detected in 10\% (3/29) ESCC cell lines. SKP2 on 5p13 was amplified and overexpressed in 50\% (23/46) ESCC tumors, and was associated with LNM and stage. SKP2 overexpression could protect cancer cells from anoikis, which was mediated in part by the phosphoinositidyl 3-kinase-Akt pathway [49]. Gains of 18p11.2-p11.3 and 18p11.3 were also found in $20.7 \%$ and $17.2 \%$ cell lines by CGH [31] and FISH [50]. AURKA at 20q13 encodes a cell cycleregulated kinase. Yang et al. found that overexpression of AURKA was existed in $85.7 \%(6 / 7)$ cell lines and 93.1\% (27/29) tumors [51]. Recent studies have reported that AURKA is a direct target of the MAPK pathway [52]. Overexpression of AURKA is independently associated with chromosomal instability in colorectal cancer [53], and AURKA expression has a prognostic value in ovarian carcinoma [54]. High-level amplifications of 11q13.3-q13.4, 7p11.2, and 8q24.21 have been observed in this study. Amplification of 11q13.3-q13.4 will be discussed later. Amplification of $7 \mathrm{p} 11.2$, which harbors an 
Table 6 Logistic regression analyses of the impact of clinico-pathological factors and 11q13.3-q13.4 splitting and amplification on LNM

\begin{tabular}{|c|c|c|c|c|c|c|}
\hline \multirow[t]{2}{*}{ Clinical features } & \multicolumn{2}{|c|}{ LNM } & \multicolumn{2}{|c|}{ Univariate analysis } & \multicolumn{2}{|c|}{ Multivariate analysis } \\
\hline & No & $\overline{\mathrm{N} 1}$ & $P$ value & RR $(95 \% \mathrm{Cl})$ & $P$ value ${ }^{a}$ & RR $(95 \% \mathrm{Cl})$ \\
\hline \multicolumn{7}{|l|}{ Gender } \\
\hline Male & 48 & 61 & 0.368 & $1.466(0.637-3.374)$ & - & \\
\hline Female & 15 & 13 & & & & \\
\hline \multicolumn{7}{|l|}{ Age } \\
\hline$<60$ & 32 & 38 & 0.948 & $0.978(0.499-1.915)$ & - & \\
\hline$\geq 60$ & 31 & 36 & & & & \\
\hline \multicolumn{7}{|l|}{ Tumor size } \\
\hline $\mathrm{T} 1, \mathrm{~T} 2$ & 11 & 9 & 0.384 & $1.528(0.589-3.964)$ & - & \\
\hline $\mathrm{T} 3, \mathrm{~T} 4$ & 52 & 65 & & & & \\
\hline \multicolumn{7}{|l|}{ Differentiation } \\
\hline G1 & 16 & 11 & 0.295 & $1.308(0.792-2.161)$ & - & \\
\hline G2 & 31 & 43 & & & & \\
\hline G3 & 16 & 20 & & & & \\
\hline \multicolumn{7}{|l|}{ Splitting status } \\
\hline Non-splitting & 44 & 32 & 0.004 & $2.822(1.384-5.757)$ & 0.026 & $2.357(1.110-5.004)$ \\
\hline Splitting & 19 & 39 & & & & \\
\hline \multicolumn{7}{|l|}{ Amplification status } \\
\hline Non-amp & 13 & 5 & 0.022 & $3.588(1.202-10.712)$ & 0.165 & $2.265(0.715-7.175)$ \\
\hline Amp & 50 & 69 & & & & \\
\hline
\end{tabular}

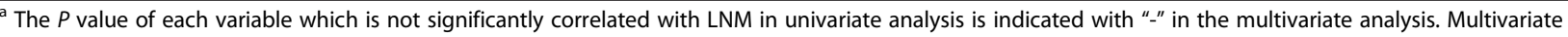
logistic regression analysis is performed using forward procedures.

LNM: lymph node metastasis; $\mathrm{RR}$, relative risk; Cl, confidence interval; amp: amplification.

important oncogene EGFR, was also found in ESCC from other studies [36]. Amplification and overexpression of EGFR gene may play roles in the invasion and progression in cancer [55], and the elevated expression may be an indicator for tumor recurrence and lower survival in head and neck squamous cell carcinoma (HNSCC) [56]. Amplification of $M Y C$ in 8q24.21 may contribute to the progression of breast cancer [57].

Losses were previously found on $3 p, 5 q, 8 p, 9 p$ and $11 q$ [36], as well as 4p16.3-q35.2, 13q12.11-q34, 18p11.32-q23, and chromosome $Y$ [38]. In our study, losses were observed on 18q12.2-qter, 3p14.1-p11, 4p15.32-p14, 4q22.1-q32.3, 9pter-p24.1, 9p23-p11, 11q23.3-qter, 18q12.2-q21.1, Xpterp11, Xq21.1-q23 in more than 50\% (3/6) of the cell lines, indicating several tumor suppressor genes may be located in these regions. 9p21.3 (CDKN2A and $C D K N 2 B)$ is homozygously deleted in some of ESCC $[58,59]$. It has been found that $C D K N 2 A$ was fused to $I G H$ through the translocation $\mathrm{t}(9 ; 14)(\mathrm{p} 21 ; \mathrm{q} 32)$ in a pre-B acute lymphoblastic leukemia cell line [60]. The functional study demonstrated that restoring wild-type CDKN $2 A$ into the gene deleted ESCC cells significantly inhibited cell invasion, suggesting that inactivation of $C D K N 2 A$ may be involved in ESCC invasion [59]. Our array-CGH results confirmed that HD frequency of 9p21.3 was $66.7 \%(4 / 6)$. Interestingly, $C D K N 2 A$ was deleted in only one cell line, and the other three harbored at least one breakpoint inside of $C D K N 2 A$. For $C D K N 2 B$, the inside breakpoint was detected in one cell line, while the other three were homozygously deleted.

Recurrent breakpoint regions were detected in at least two cell lines, including 1q31.1, 2q35, 3p14.2, 3q12.1q12.2, 3q28, 4p13, 4q22.1, 6p12.3-p12.2, 6p22.2-p22.1, 7q22.2-q22.3, 8q24.21, 9p21.3, 10q26.3, 11p13, 11q13.3, 11q13.4, 13q21.32, 15q25.3, 18q12.2 and 21q21.1. Many of these breakpoints were different from those detected by SKY in other ESCC cell lines [35]. The correlation between breakpoints of fusion genes and fragile sites has been emphasized in previous studies. Burrow et al. analyzed 444 pairs of genes involved in cancer-specific recurrent translocations, and found that $52 \%$ of the breakpoints in at least one gene of the fusion-gene pairs were localized within the vicinity of a fragile site [61]. Thus, understanding breakpoints near fragile sites may be helpful for further discovering cancer-related gene rearrangements.

$11 \mathrm{q} 13$ is an important region that presents various aberrations in many malignancies. Gain of 11q13 has 
previously been described in ESCC [34,36-38,62,63] and other solid tumors, including oral [42], gastric [64], breast [65-67], ovarian [68], prostate [69], bladder [70], laryngeal [71], nasopharyngeal [72], and liver tumors [73] as well as head and neck [74,75] cancer. Gain frequencies of 11q13 varied between studies. The probable target genes that are amplified and/or overexpressed in different cancers have been reported to include CCND1 [62,76,77], FGF4 [62,78], PPFIA1 [67], CTTN [62,76] and ORAOV1 [79]. We observed that 11q13.3-q13.4 was a region with high-level amplification adjacent to the breakpoint boundaries. Breakpoints in 11q13.4 and 11q13.3 were both found in two cell lines, and breakpoints that were identified in 11q13.4 between KYSE30 and KYSE510 were closer to each other. Furthermore, breakpoints in the entire region of 11q13.3-q13.4 were present in more than $40 \%$ of ESCC tumors, suggesting that $11 \mathrm{q} 13.3-\mathrm{q} 13.4$ may be a frequently split region in ESCCs.

$11 \mathrm{q} 13$ is also involved in various chromosomal rearrangements in both hematological malignancies and epithelial carcinomas. The $\mathrm{t}(11 ; 14)(\mathrm{q} 13 ; \mathrm{q} 32)$ translocation is associated with $70 \%-90 \%$ of mantle cell lymphomas (MCL) [80,81], a small portion of multiple myeloma (MM) [81,82], acute myeloid leukemia (AML) [83] and other lymphoproliferative disorders [84]. As a result of this translocation, CCND1 is fused to the enhancer of immunoglobulin heavy chain gene $(I G H)$, and thus overexpressed in MCL and MM [81]. MYEOV, proximal to $C C N D 1$, was also overexpressed in a subset of $\mathrm{t}(11 ; 14)$ positive MM cell lines, in which both MYEOV and $C C N D 1$ were under the control of $I G H$ enhancers due to translocations [85]. There are also other partner genes fused to CCND1, including $I G K$ involved in $\mathrm{t}(2 ; 11)(\mathrm{p} 11$; q13) in leukemic small-cell B-non-Hodgkin lymphoma (NHL) [86] and an unknown partner gene in AML with $\mathrm{t}(5 ; 11)(\mathrm{q} 35 ; \mathrm{q} 13)$ [87]. 11q13 rearrangements with 6p21, $7 q 11.2,1 \mathrm{p} 13$ and $5 \mathrm{q} 35$ were observed in renal oncocytoma. Jhang et al. demonstrated that CCND1 was overexpressed only in the cases with 11q13 translocation. However, not all of the cases with 11q13 translocations could lead to CCND1 overexpression [88]. Evidence of fusions involving other genes in $11 \mathrm{q} 13$ has been reported. NUMA-RARA and RUNX1-MACROD1 were present in the monocytic leukemia with $\mathrm{t}(11 ; 17)(\mathrm{q} 13$; q21) [89-91] and APL with $\mathrm{t}(11 ; 21)(\mathrm{q} 13 ; \mathrm{q} 22)$ [92], respectively. Rearrangement of LRP5 was found in AML, although the partner gene has not been identified [93]. Most of the above translocations in lymphomas and leukemia are balanced and not complicated, while more complex rearrangements of 11q13 were detected in epithelial carcinomas, including cervical carcinoma cell lines [94], serous ovarian adenocarcinoma [95], hepatocellular carcinoma [96], gastric cancer [97] and oral squamous cell carcinoma (OSCC) $[98,99]$. Our M-FISH results were much similar to the observations in these carcinomas. We found that chromosome 11 was frequently rearranged, especially in KYSE30, KYSE150 and KYSE510. In each cell line, five to six derivative chromosomes associated with chromosome 11 were easily found, and some complex derivative chromosomes involved q13 band of the chromosome. Genes involved in breakpoints of these rearrangements remain to be clarified.

The current array-CGH profiling enabled us to set the boundaries of 11q13 amplicons in ESCC cell lines. We observed that multiple breakpoints existed in high level amplification regions involving 11q13.3 were located in 67-72 Mb position in three ESCC cell lines we detected and ten online cell lines, which is similar to the amplification peak in HNSCC [75]. The mechanisms for formation of several amplicons have been well described by a model of breakage-fusion-bridge (BFB) cycle. According to this model, the formation of amplicons is initiated by distal DNA breakages at fragile sites. During DNA replication, a dicentric chromosome with an inverted duplication may be resulted from the sister chromatid fusion (SCF). Breakage-fusion-bridge cycle may continue when another break between two centromeres occurs. The cycle may be then stabilized by a telomere or by translocation [42,98,100-102]. Albertson suggested that amplicon boundaries might also be set by selection for overexpressed genes in the amplicons, or by selection against expression changes of genes outside of amplified regions induced by CNAs [101,103]. 11q13 harbors three fragile sites, FRA11A, FRA11H and FRA11F [104]. $F R A 11 A$ is a rare fragile site, while $F R A 11 H$ and $F R A 11 F$ are common fragile sites. FRA11A is located between RIN1 (11q13.2) and CCND1 (11q13.3) [98]. FRA11H is positioned at $11 \mathrm{q} 13$, but the exact location still needs to be characterized. FRA11F is located between the BAC clones of RP11-281H14 and RP11-841F15 in 11q14.2 [42]. Reshmi et al. found that OSCC cell lines with complex 11q rearrangements were affected by FRA11F, and gene amplifications in $11 \mathrm{q} 13$ region in OSCC cell lines may be initiated by breakage at FRA11F [42]. Shuster et al. demonstrated that breakages at FRA11A between RIN1 and CCND1 may promote the BFB cycles [98]. They also found the involvement of $F R A 11 H$ in some OSCC cases with amplifications of genes in $11 \mathrm{q} 13$ $[42,105]$. In the present study, distal boundaries of amplicons in the majority of ESCC cell lines and primary tumors with $11 \mathrm{q} 13$ amplification were clustered within 67-72 Mb region of 11q13.3, which may involve FRA11H breakages for these cases. Another breakpoint was observed at NAALAD2 gene in KYSE510, and it was located within FRA11F. In addition, breakpoints proximal of 11q13 amplicons in KYSE180, KYSE510 and five 
online cell lines were located in FRA11A region in 11q13.3, while the proximal breakpoints in KYSE30 and other online cell lines were distal to FRA11A or in $F R A 11 H$. In the tested ESCC tumors, the majority of breakpoints in 11q13.3(1) were proximal to the amplicons, and most of those in 11q13.3(2) and 11q13.4 were distal to the amplicons. Thus, we speculate that initial distal breakages may primarily occur at $F R A 11 H$, and the process may involve FRA11F in some cases. FRA11A or $F R A 11 H$ may contribute to setting amplicon boundaries by promoting subsequent steps of BFB cycle. Concerning the presentation of multiple breakpoint boundaries in some of ESCC cell lines and primary tumors with high-level amplification of 11q13, several cycles of random breakages may be undergone.

In the current study, we have noticed that copy numbers of the regions from centromere to boundaries at initial breaks were higher than those of the regions distal to breakpoints in most of ESCC cell lines with 11q13 amplifications. Gains of proximal regions, losses of distal regions, intrachromosomal or interchromosomal rearrangements of 11q13 have been found in the cell lines or primary tumors of human cancer and demonstrated to be indicators of BFB cycle $[98,101]$. At the end of BFB cycles, distal breakpoints of 11q13.3-q13.4 amplicon may undergo intrachromosomal rearrangements or translocating to other chromosomes, which may affect genes at distal boundaries through forming intragenic rearrangements or fusing to other genes. Notably, most of 11q13.3-q13.4 splitting cell lines according to our and online array-CGH data showed high-level amplification of $11 \mathrm{q} 13$ proximal or distal to the breakpoints in ESCC cell lines and primary tumors. Moreover, amplicons involving intrachromosomal or interchromosomal rearrangements have also been detected. Thus, recurrent breakage at 11q13.3-q13.4 may reflect the following aspects. On one hand, genes between two BACs flanking the regions may be amplified, with proximal gain and gene overexpression. On the other hand, breakages between two BACs and thus rearrangements of genes at the amplicon boundaries may also dysregulate expression of these genes.

The relationship between gain of $11 \mathrm{q} 13$ and LNM or prognosis have been analyzed and discussed in several studies. However, contrary opinions still exist. Tada et al. conducted CGH on 36 ESCC specimens, and demonstrated that gain of $11 \mathrm{q} 13$ did not occur at a significantly different rate between LNM and non-LNM groups [106]. Genes located in 11q13 were analyzed. Amplification of CTTN was correlated with LNM, while no significant association was found between CCND1 amplification and LNM [76], however, predicting CCND1 amplification using plasma DNA may be an independent prognostic factor in ESCCs [107]. Komatsu et al. found that overexpression of ORAOV1 showed a significant association with LNM and stages. Gain of 11q13.2 was determined to be an independent prognostic factor for predicting poor outcome, and amplification of CPT1A in 11q13.2 was correlated with shorter overall survival in ESCC. Here, we found the correlation between 11q13.3-q13.4 amplification and LNM as well as advanced stages. The relationship between gene status in $11 \mathrm{q} 13$ and LNM has also been evaluated in other cancers. Amplification of 11q13 DNA is associated with lymph node involvement in HNSCC [108]. CCND1 amplification and overexpression are significantly associated with LNM and survival in OSCC [109]. Another study confirmed amplifications of 11 genes in 11q13, and found two amplification cores, including core 1 (TPCN2 and MYEOV), and core 2 (from CCND1 to $C T T N$ ). Amplification of CTTN (core 2) and/or TPCN2/ $M Y E O V$ (core 1) was further demonstrated to be associated with LNM in OSCC [110]. However, Huang et al. reported that there was no correlation between LNM and amplification or expression of the tested genes in $11 \mathrm{q} 13$ in OSCC [111]. Fortin et al. also found 11q13 amplifications not appear to be a reliable marker for subclinical LNM prediction in oral and oropharyngeal carcinomas [112]. A study by Xia et al. indicated that amplifications of ORAOV1 and CTTN are indicated to be associated with LNM [113]. In the breast cancer, PPFIA1 is coamplified with CCND1, which is significantly associated with high-grade phenotype but not tumor stage or nodal stage [67].

In this report, we demonstrated that both of 11q13.3q13.4 splitting and amplification are significantly correlated with LNM and advanced stages, indicating that breakage and amplification of this region may play important roles in the tumor progression. According to multivariate logistic regression analysis, however, it was splitting rather than amplification that could be an independent predictor for the higher tendency of metastasis. In addition, two smaller regions 11q13.4(1) (SHANK2, DHCR7, NADSYN1, KRTAP5-7, KRTAP5-8, KRTAP5-9, KRTAP5-10, KRTAP5-11, FAM86C1, RNF121, IL18BP, NUMA1, LRTOMT, FOLR3, FOLR1, FOLR2, INPPL1, $P H O X 2 A$ and CLPB) and 11q13.3(2)-q13.4(1) (CCND1, ORAOV1, FGF19, FGF4, FGF3, ANO1, FADD, PPFIA1, CTTN, SHANK2, DHCR7, NADSYN1, KRTAP5-7, KRTAP5-8, KRTAP5-9, KRTAP5-10, KRTAP5-11, FAM86C1, RNF121, IL18BP, NUMA1, LRTOMT, FOLR3, FOLR1, FOLR2, INPPL1, PHOX2A and CLPB) and were also associated with these parameters. However, no significant difference was found for 11q13.3(1) (CPT1A, MRPL21, IGHMBP2, MRGPRD, MRGPRT, TPCN2, $M Y E O V)$. These results suggested that genes located in 11q13.3(2) and 11q13.4(1) may play more important roles in LNM than 11q13.3(1). It will be interesting to 
further investigate gene and protein alterations caused by genomic breakages. Since the exact breakpoint locations may be distinctive in different cases, further studies will be focused on determining which of these genes were rearranged or disrupted in specific cases, identifying possible rearranged forms and roles of these alterations may play in ESCC development.

\section{Conclusions}

Our data provide detailed information on chromosomal and genomic aberrations present in six ESCC cell lines. Using a combination of M-FISH and array-CGH enabled us to produce more accurate karyotypes, which will help to determine appropriate applications of these cell lines for cytogenetic and molecular biological studies. The recurrent genomic breakpoints present in both the cell lines and primary tumors may help to identify aberrant genes associated with the development and progression of ESCC.

\section{Additional files}

Additional file 1: Table S1. Genomic copy number alterations in ESCC cell lines detected by array-CGH.

Additional file 2: Table S2. Regions of gain and the frequencies in the ESCC cell lines.

Additional file 3: Table S3. Unbalanced breakpoints analyzed according to the copy number alterations.

Additional file 4: Figure S1. High level amplifications and breakages of 11 q13 in ten ESCC cell lines. (A) KYSE140, (B) KYSE410, (C) EC-Gl-10, (D) HCE-4, (E) TE-6, (F) TE-8, (G) TE-9, (H) TE-10, (I) TE-11, (J) TE-15. Amplifications are mainly located within 67-72 Mb position. The smallest amplification region is similar to previously reported. More than two breakpoints are present in most of the cell lines, revealing these positions may be highly rearranged.

Additional file 5: Table S4. Splitting and amplification of 11q13.3-q13.4 in the primary ESCC tumors by FISH analyses.

Additional file 6: Table S5. Clinico-pathological parameters of the examined ESCC patients.

Additional file 7: Table S6. Relationship between region splittings and clinico-pathological features of ESCC.

Additional file 8: Table S7. Relationship between region amplifications and clinico-pathological features of ESCC.

\section{Competing interests}

There was no conflict of interest in this study.

\section{Authors' contributions}

HJJ carried out M-FISH experiments, participated in the data analyses, and draft the manuscript. SZZ carried out array-CGH experiments. ZZX organized clinico-pathological information. ZY participated in the design of the study. GT carried out part of the FISH experiments. LCX carried out part of the FISH experiments. ZT performed some statistical analysis. CY performed some statistical analysis. DJT provided FISH probe templates (BAC-DNA) and gave experimental suggestions. FSB provided the statistical analysis suggestion. ZQM gave experimental design suggestions. WMR conceived of the study, and participated in its design and coordination and helped to draft the manuscript. All authors have read and approved the final manuscript.

\section{Acknowledgements}

We thank Professor Hong Chen (Basic Medical Institute, Chinese Academy of Medical Sciences \& Peking Union Medical College, Beijing, China) for the kind gift of Whole-chromosome painting (WCP) probes. This work was supported by Chinese Hi-Tech R\&D Program Grant (2012AA02A503), National Science Fund $(81021061,30872936)$ and Specialized Research Fund for the Doctoral Program of Higher Education of China (20101106110015).

\section{Author details}

${ }^{1}$ State Key Laboratory of Molecular Oncology, Cancer Institute (Hospital), Peking Union Medical College and Chinese Academy of Medical Science, 17 Panjiayuan Nanli, Chaoyang District, Beijing 100021, China. ${ }^{2}$ Pathology department, Tongliao Hospital, 16 Keerqin Road, Tongliao 028000, China. ${ }^{3}$ Laboratory of Medical Genetics, Harbin Medical University, Harbin 150081, China. "Winship Cancer Institute, Emory University School of Medicine, 1365-C Clifton Road, Atlanta, GA 30322, USA.

Received: 23 December 2011 Accepted: 17 August 2012 Published: 24 August 2012

\section{References}

1. Frohling S, Dohner $\mathrm{H}$ : Chromosomal abnormalities in cancer. $N$ Engl J Med 2008, 359(7):722-734.

2. Ritz A, Paris PL, Ittmann MM, Collins C, Raphael BJ: Detection of recurrent rearrangement breakpoints from copy number data. BMC Bioinformatics 2011, 12:114.

3. Mitelman F, Johansson B, Mertens F: The impact of translocations and gene fusions on cancer causation. Nat Rev Cancer 2007, 7(4):233-245.

4. Edwards PA: Fusion genes and chromosome translocations in the common epithelial cancers. J Pathol 2010, 220(2):244-254.

5. Clark JP, Cooper CS: ETS gene fusions in prostate cancer. Nat Rev Urol 2009, 6(8):429-439.

6. Berger MF, Lawrence MS, Demichelis F, Drier Y, Cibulskis K, Sivachenko AY, Sboner A, Esgueva R, Pflueger D, Sougnez C, et al: The genomic complexity of primary human prostate cancer. Nature 2011 470(7333):214-220.

7. Stephens PJ, McBride DJ, Lin ML, Varela I, Pleasance ED, Simpson JT, Stebbings LA, Leroy C, Edkins S, Mudie L, et al: Complex landscapes of somatic rearrangement in human breast cancer genomes. Nature 2009, 462(7276):1005-1010.

8. Inaki K, Hillmer AM, Ukil L, Yao F, Woo XY, Vardy LA, Zawack KF, Lee CW, Ariyaratne PN, Chan YS, et al: Transcriptional consequences of genomic structural aberrations in breast cancer. Genome Res 2011, 21(5):676-687.

9. Kohno T, Ichikawa H, Totoki Y, Yasuda K, Hiramoto M, Nammo T, Sakamoto $H$, Tsuta K, Furuta K, Shimada Y, et al: KIF5B-RET fusions in lung adenocarcinoma. Nat Med 2012, 18(3):375-377.

10. Ju YS, Lee WC, Shin JY, Lee S, Bleazard T, Won JK, Kim YT, Kim Jl, Kang JH, Seo JS: A transforming KIF5B and RET gene fusion in lung adenocarcinoma revealed from whole-genome and transcriptome sequencing. Genome Res 2012, 22(3):436-445.

11. Bass AJ, Lawrence MS, Brace LE, Ramos AH, Drier Y, Cibulskis K, Sougnez C, Voet D, Saksena G, Sivachenko A, et al: Genomic sequencing of colorectal adenocarcinomas identifies a recurrent VTI1A-TCF7L2 fusion. Nat Genet 2011, 43(10):964-968.

12. Palanisamy N, Ateeq B, Kalyana-Sundaram S, Pflueger D, Ramnarayanan K, Shankar S, Han B, Cao Q, Cao X, Suleman K, et al: Rearrangements of the RAF kinase pathway in prostate cancer, gastric cancer and melanoma. Nat Med 2010, 16(7):793-798.

13. Stransky N, Egloff AM, Tward AD, Kostic AD, Cibulskis $K$, Sivachenko A, Kryukov GV, Lawrence MS, Sougnez C, McKenna A, et al: The mutational landscape of head and neck squamous cell carcinoma. Science 2011 333(6046):1157-1160.

14. Totoki Y, Tatsuno K, Yamamoto S, Arai Y, Hosoda F, Ishikawa S, Tsutsumi S, Sonoda K, Totsuka H, Shirakihara T, et al: High-resolution characterization of a hepatocellular carcinoma genome. Nat Genet 2011 , 43(5):464-469

15. Tomlins SA, Rhodes DR, Perner S, Dhanasekaran SM, Mehra R, Sun XW Varambally S, Cao X, Tchinda J, Kuefer R, et al: Recurrent fusion of TMPRSS2 and ETS transcription factor genes in prostate cancer. Science 2005, 310(5748):644-648. 
16. Speicher MR: Gwyn Ballard S, Ward DC: Karyotyping human chromosomes by combinatorial multi-fluor FISH. Nat Genet 1996, 12(4):368-375

17. Schrock E, du Manoir S, Veldman T, Schoell B, Wienberg J, Ferguson-Smith MA, Ning Y, Ledbetter DH, Bar-Am I, Soenksen D, et al: Multicolor spectral karyotyping of human chromosomes. Science 1996, 273(5274):494-497.

18. Pinkel D, Segraves R, Sudar D, Clark S, Poole I, Kowbel D, Collins C, Kuo WL, Chen C, Zhai $Y$, et al: High resolution analysis of DNA copy number variation using comparative genomic hybridization to microarrays. Nat Genet 1998, 20(2):207-211.

19. Speicher MR, Carter NP: The new cytogenetics: blurring the boundaries with molecular biology. Nat Rev Genet 2005, 6(10):782-792.

20. Camps J, Grade M, Nguyen QT, Hormann P, Becker S, Hummon AB, Rodriguez V, Chandrasekharappa S, Chen Y, Difilippantonio MJ, et al: Chromosomal breakpoints in primary colon cancer cluster at sites of structural variants in the genome. Cancer Res 2008, 68(5):1284-1295.

21. Mao X, James SY, Yanez-Munoz RJ, Chaplin T, Molloy G, Oliver RT, Young $B D, L u$ YJ: Rapid high-resolution karyotyping with precise identification of chromosome breakpoints. Genes Chromosomes Cancer 2007 46(7):675-683

22. Watson SK, DeLeeuw RJ, Horsman DE, Squire JA, Lam WL: Cytogenetically balanced translocations are associated with focal copy number alterations. Hum Genet 2007, 120(6):795-805.

23. Kawamata N, Ogawa S, Zimmermann M, Niebuhr B, Stocking C, Sanada M, Hemminki K, Yamatomo G, Nannya Y, Koehler R, et al: Cloning of genes involved in chromosomal translocations by high-resolution single nucleotide polymorphism genomic microarray. Proc Natl Acad Sci U S A 2008, 105(33):11921-11926.

24. Persson F, Winnes M, Andren $Y$, Wedell B, Dahlenfors R, Asp J, Mark J, Enlund F, Stenman G: High-resolution array CGH analysis of salivary gland tumors reveals fusion and amplification of the FGFR1 and PLAG1 genes in ring chromosomes. Oncogene 2008, 27(21):3072-3080.

25. Howarth KD, Blood KA, Ng BL, Beavis JC, Chua Y, Cooke SL, Raby S, Ichimura $K$, Collins VP, Carter NP, et al: Array painting reveals a high frequency of balanced translocations in breast cancer cell lines that break in cancerrelevant genes. Oncogene 2008, 27(23):3345-3359.

26. Jemal A, Bray F, Center MM, Ferlay J, Ward E, Forman D: Global cancer statistics. CA Cancer J Clin 2011, 61(2):69-90.

27. Parkin DM, Bray Fl, Devesa SS: Cancer burden in the year 2000. The global picture. Eur J Cancer 2001, 37(Suppl 8):S4-66.

28. Wu YP, Yang YL, Yang GZ, Wang XY, Luo ML, Zhang Y, Feng YB, Xu X, Han $Y L$, Cai $Y$, et al: Identification of chromosome aberrations in esophageal cancer cell line KYSE180 by multicolor fluorescence in situ hybridization. Cancer Genet Cytogenet 2006, 170(2):102-107.

29. Wu YP, Yang YL, Han YL, Xu X, Cai Y, Yang GZ, Wang XY, Zhan QM, Wu M, Wang MR: Identification of complex chromosome abnormalities in esophageal carcinoma cells KYSE450 by multicolor fluorescence in situ hybridization. Shijie Huaren Xiaohua Zazhi 2006, 14(8):747-751.

30. Yang Y, Chu J, Wu Y, Luo M, Xu X, Han Y, Cai Y, Zhan Q, Wang M: Chromosome analysis of esophageal squamous cell carcinoma cell line KYSE 410-4 by repetitive multicolor fluorescence in situ hybridization. $J$ Genet Genomics 2008, 35(1):11-16.

31. Pimkhaokham A, Shimada Y, Fukuda Y, Kurihara N, Imoto I, Yang ZQ Imamura M, Nakamura Y, Amagasa T, Inazawa J: Nonrandom chromosomal imbalances in esophageal squamous cell carcinoma cell lines: possible involvement of the ATF3 and CENPF genes in the 1q32 amplicon. Jpn J Cancer Res 2000, 91(11):1126-1133.

32. Wei F, Ni J, Wu SS, Liu H, Xu X, Han YL, Cai Y, Zhang JW, Chen XJ, Pang H, et al: Cytogenetic studies of esophageal squamous cell carcinomas in the northern Chinese population by comparative genomic hybridization. Cancer Genet Cytogenet 2002, 138(1):38-43.

33. Qin YR, Wang LD, Fan ZM, Kwong D, Guan XY: Comparative genomic hybridization analysis of genetic aberrations associated with development of esophageal squamous cell carcinoma in Henan, China. World J Gastroenterol 2008, 14(12):1828-1835.

34. Sakai N, Kajiyama $Y$, Iwanuma $Y$, Tomita N, Amano T, Isayama F, Ouchi K, Tsurumaru M: Study of abnormal chromosome regions in esophageal squamous cell carcinoma by comparative genomic hybridization: relationship of lymph node metastasis and distant metastasis to selected abnormal regions. Dis Esophagus 2010, 23(5):415-421.
35. Yen CC, Chen YJ, Lu KH, Hsia JY, Chen JT, Hu CP, Chen PM, Liu JH, Chiou TJ, Wang WS, et al: Genotypic analysis of esophageal squamous cell carcinoma by molecular cytogenetics and real-time quantitative polymerase chain reaction. Int J Oncol 2003, 23(4):871-881.

36. Carneiro A, Isinger A, Karlsson A, Johansson J, Jonsson G, Bendahl PO, Falkenback D, Halvarsson B, Nilbert M: Prognostic impact of array-based genomic profiles in esophageal squamous cell cancer. BMC Cancer 2008 8:98.

37. Hu N, Wang C, Ng D, Clifford R, Yang HH, Tang ZZ, Wang QH, Han XY, Giffen C, Goldstein AM, et al: Genomic characterization of esophageal squamous cell carcinoma from a high-risk population in China. Cancer Res 2009, 69(14):5908-5917.

38. Shi ZZ, Liang JW, Zhan T, Wang BS, Lin DC, Liu SG, Hao JJ, Yang H, Zhang Y, Zhan QM, et al: Genomic alterations with impact on survival in esophageal squamous cell carcinoma identified by array comparative genomic hybridization. Genes Chromosomes Cancer 2011, 50(7):518-526.

39. Telenius H, Carter NP, Bebb CE, Nordenskjold M, Ponder BA, Tunnacliffe A: Degenerate oligonucleotide-primed PCR: general amplification of target DNA by a single degenerate primer. Genomics 1992, 13(3):718-725.

40. Albertson DG, Collins C, McCormick F, Gray JW: Chromosome aberrations in solid tumors. Nat Genet 2003, 34(4):369-376.

41. Nambiar M, Kari V, Raghavan SC: Chromosomal translocations in cancer. Biochim Biophys Acta 2008, 1786(2):139-152

42. Reshmi SC, Huang X, Schoppy DW, Black RC, Saunders WS, Smith DI, Gollin SM: Relationship between FRA11F and 11q13 gene amplification in oral cancer. Genes Chromosomes Cancer 2007, 46(2):143-154.

43. Ueno T, Tangoku A, Yoshino S, Abe T, Toshimitsu H, Furuya T, Kawauchi S, Oga A, Oka M, Sasaki K: Gain of 5 p15 detected by comparative genomic hybridization as an independent marker of poor prognosis in patients with esophageal squamous cell carcinoma. Clin Cancer Res 2002, 8(2):526-533.

44. Tada K, Oka M, Hayashi H, Tangoku A, Oga A, Sasaki K: Cytogenetic analysis of esophageal squamous cell carcinoma cell lines by comparative genomic hybridization: relationship of cytogenetic aberrations to in vitro cell growth. Cancer Genet Cytogenet 2000, 117(2):108-112.

45. Akagi I, Miyashita M, Makino H, Nomura T, Hagiwara N, Takahashi K, Cho K, Mishima T, Ishibashi O, Ushijima T, et al: Overexpression of PIK3CA is associated with lymph node metastasis in esophageal squamous cell carcinoma. Int J Oncol 2009, 34(3):767-775.

46. Yang $Y L$, Chu JY, Luo ML, Wu YP, Zhang Y, Feng YB, Shi ZZ, Xu X, Han YL, Cai $Y$, et al: Amplification of PRKCl, located in $3 q 26$, is associated with lymph node metastasis in esophageal squamous cell carcinoma. Genes Chromosomes Cancer 2008, 47(2):127-136.

47. Imoto I, Yuki $Y$, Sonoda I, Ito T, Shimada $Y$, Imamura M, Inazawa J: Identification of ZASC1 encoding a Kruppel-like zinc finger protein as a novel target for 3 q26 amplification in esophageal squamous cell carcinomas. Cancer Res 2003, 63(18):5691-5696.

48. Wada S, Noguchi T, Takeno S, Kawahara K: PIK3CA and TFRC located in $3 q$ are new prognostic factors in esophageal squamous cell carcinoma. Ann Surg Oncol 2006, 13(7):961-966.

49. Wang XC, Wu YP, Ye B, Lin DC, Feng YB, Zhang ZQ, Xu X, Han YL, Cai $Y$, Dong JT, et al: Suppression of anoikis by SKP2 amplification and overexpression promotes metastasis of esophageal squamous cell carcinoma. Mol Cancer Res 2009, 7(1):12-22

50. Nakakuki K, Imoto I, Pimkhaokham A, Fukuda Y, Shimada Y, Imamura M, Amagasa T, Inazawa J: Novel targets for the 18p11.3 amplification frequently observed in esophageal squamous cell carcinomas. Carcinogenesis 2002, 23(1):19-24.

51. Yang SB, Zhou XB, Zhu HX, Quan LP, Bai JF, He J, Gao YN, Cheng SJ, Xu NZ: Amplification and overexpression of Aurora- $A$ in esophageal squamous cell carcinoma. Oncol Rep 2007, 17(5):1083-1088.

52. Furukawa T, Kanai N, Shiwaku HO, Soga N, Uehara A, Horii A: AURKA is one of the downstream targets of MAPK1/ERK2 in pancreatic cancer. Oncogene 2006, 25(35):4831-4839.

53. Baba Y, Nosho K, Shima K, Irahara N, Kure S, Toyoda S, Kirkner GJ, Goel A, Fuchs CS, Ogino S: Aurora-A expression is independently associated with chromosomal instability in colorectal cancer. Neoplasia 2009, 11(5):418-425

54. Mendiola M, Barriuso J, Marino-Enriquez A, Redondo A, Dominguez-Caceres A, Hernandez-Cortes G, Perez-Fernandez E, Sanchez-Navarro I, Vara JA, 
Suarez $A$, et al: Aurora kinases as prognostic biomarkers in ovarian carcinoma. Hum Pathol 2009, 40(5):631-638.

55. Miyai K, Yamamoto S, Asano T, Tamai S, Matsubara O, Tsuda H: Protein overexpression and gene amplification of epidermal growth factor receptor in adult testicular germ cell tumors: potential role in tumor progression. Cancer Sci 2010, 101(9):1970-1976.

56. Rubin Grandis J, Melhem MF, Gooding WE, Day R, Holst VA, Wagener MM, Drenning SD, Tweardy DJ: Levels of TGF-alpha and EGFR protein in head and neck squamous cell carcinoma and patient survival. J Natl Cancer Inst 1998, 90(11):824-832.

57. Singhi AD, Cimino-Mathews $A$, Jenkins RB, Lan F, Fink SR, Nassar $H$, Vang $R$, Fetting JH, Hicks J, Sukumar S, et al: MYC gene amplification is often acquired in lethal distant breast cancer metastases of unamplified primary tumors. Mod Pathol 2012, 25(3):378-387.

58. Maesawa C, Tamura G, Nishizuka S, Ogasawara S, Ishida K, Terashima M, Sakata K, Sato N, Saito K, Satodate R: Inactivation of the CDKN2 gene by homozygous deletion and de novo methylation is associated with advanced stage esophageal squamous cell carcinoma. Cancer Res 1996, 56(17):3875-3878.

59. Kim DH, Muto M, Kuwahara Y, Nakanishi Y, Watanabe H, Aoyagi K, Ogawa K, Yoshida T, Sasaki H: Array-based comparative genomic hybridization of circulating esophageal tumor cells. Oncol Rep 2006, 16(5):1053-1059.

60. Urashima M, Hoshi Y, Sugimoto Y, Kaihara C, Matsuzaki M, Chauhan D, Ogata A, Teoh G, DeCaprio JA, Anderson KC: A novel pre-B acute lymphoblastic leukemia cell line with chromosomal translocation between p16(INK4A)/p15(INK4B) tumor suppressor and immunoglobulin heavy chain genes: TGFbeta/lL-7 inhibitory signaling mechanism. Leukemia 1996, 10(10):1576-1583.

61. Burrow AA, Williams LE, Pierce LC, Wang YH: Over half of breakpoints in gene pairs involved in cancer-specific recurrent translocations are mapped to human chromosomal fragile sites. BMC Genomics 2009, 10:59.

62. Arai H, Ueno T, Tangoku A, Yoshino S, Abe T, Kawauchi S, Oga A, Furuya T, Oka M, Sasaki K: Detection of amplified oncogenes by genome DNA microarrays in human primary esophageal squamous cell carcinoma: comparison with conventional comparative genomic hybridization analysis. Cancer Genet Cytogenet 2003, 146(1):16-21.

63. Hirasaki S, Noguchi T, Mimori K, Onuki J, Morita K, Inoue H, Sugihara K, Mori M, Hirano T: BAC clones related to prognosis in patients with esophageal squamous carcinoma: an array comparative genomic hybridization study. Oncologist 2007, 12(4):406-417.

64. Kuroda A, Tsukamoto Y, Nguyen LT, Noguchi T, Takeuchi I, Uchida M, Uchida T, Hijiya N, Nakada C, Okimoto T, et al: Genomic profiling of submucosal-invasive gastric cancer by array-based comparative genomic hybridization. PLoS One 2011, 6(7):e22313

65. Letessier A, Sircoulomb F, Ginestier C, Cervera N, Monville F, Gelsi-Boyer V, Esterni B, Geneix J, Finetti $P$, Zemmour $C$, et al: Frequency, prognostic impact, and subtype association of $8 \mathrm{p} 12,8 \mathrm{q} 24,11 \mathrm{q} 13,12 \mathrm{p} 13,17 \mathrm{q} 12$ and 20q13 amplifications in breast cancers. BMC Cancer 2006, 6:245.

66. Kwek SS, Roy R, Zhou H, Climent J, Martinez-Climent JA, Fridlyand J, Albertson DG: Co-amplified genes at $8 p 12$ and $11 q 13$ in breast tumors cooperate with two major pathways in oncogenesis. Oncogene 2009, 28(17):1892-1903.

67. Dancau AM, Wuth L, Waschow M, Holst F, Krohn A, Choschzick M, Terracciano L, Politis S, Kurtz S, Lebeau A, et al: PPFIA1 and CCND1 are frequently coamplified in breast cancer. Genes Chromosomes Cancer 2010, 49(1):1-8.

68. Tan DS, Lambros MB, Rayter S, Natrajan R, Vatcheva R, Gao Q, Marchio C, Geyer FC, Savage K, Parry S, et al: PPM1D is a potential therapeutic target in ovarian clear cell carcinomas. Clin Cancer Res 2009, 15(7):2269-2280

69. Das K, Lau W, Sivaswaren C, Ph T, Fook-Chong S, SI T, Cheng C: Chromosomal changes in prostate cancer: a fluorescence in situ hybridization study. Clin Genet 2005, 68(1):40-47.

70. Zaharieva BM, Simon R, Diener PA, Ackermann D, Maurer R, Alund G, Knonagel $H$, Rist M, Wilber $K$, Hering F, et al: High-throughput tissue microarray analysis of $11 \mathrm{q} 13$ gene amplification (CCND1, FGF3, FGF4, EMS1) in urinary bladder cancer. J Pathol 2003, 201(4):603-608.

71. Jarmuz M, Grenman R, Golusinski W, Szyfter K: Aberrations of 11q13 in laryngeal squamous cell lines and their prognostic significance. Cancer Genet Cytogenet 2005, 160(1):82-88.
72. Hui AB, Or YY, Takano H, Tsang RK, To KF, Guan XY, Sham JS, Hung KW, Lam $\mathrm{CN}$, van Hasselt CA, et al: Array-based comparative genomic hybridization analysis identified cyclin D1 as a target oncogene at 11q13.3 in nasopharyngeal carcinoma. Cancer Res 2005, 65(18):8125-8133.

73. Wen JM, Huang JF, Hu L, Wang WS, Zhang M, Sham JS, Xu JM, Zeng WF, Xie D, Liang $L$, et al: Establishment and characterization of human metastatic hepatocellular carcinoma cell line. Cancer Genet Cytogenet 2002, 135(1):91-95.

74. Jin C, Jin Y, Gisselsson D, Wennerberg J, Wah TS, Stromback B, Kwong YL, Mertens F: Molecular cytogenetic characterization of the $11 \mathrm{q} 13$ amplicon in head and neck squamous cell carcinoma. Cytogenet Genome Res 2006, 115(2):99-106.

75. Gibcus JH, Kok K, Menkema L, Hermsen MA, Mastik M, Kluin PM, van der Wal JE, Schuuring E: High-resolution mapping identifies a commonly amplified 11q13.3 region containing multiple genes flanked by segmental duplications. Hum Genet 2007, 121(2):187-201.

76. Luo ML, Shen XM, Zhang Y, Wei F, XU X, Cai Y, Zhang X, Sun YT, Zhan QM, Wu M, et al: Amplification and overexpression of CTTN (EMS1) contribute to the metastasis of esophageal squamous cell carcinoma by promoting cell migration and anoikis resistance. Cancer Res 2006 , 66(24):11690-11699.

77. Jin Y, Jin C, Law S, Chu KM, Zhang H, Strombeck B, Yuen AP, Kwong YL: Cytogenetic and fluorescence in situ hybridization characterization of clonal chromosomal aberrations and CCND1 amplification in esophageal carcinomas. Cancer Genet Cytogenet 2004, 148(1):21-28.

78. Ishizuka T, Tanabe C, Sakamoto H, Aoyagi K, Maekawa M, Matsukura N, Tokunaga A, Tajiri T, Yoshida T, Terada M, et al: Gene amplification profiling of esophageal squamous cell carcinomas by DNA array CGH. Biochem Biophys Res Commun 2002, 296(1):152-155.

79. Komatsu Y, Hibi K, Kodera Y, Akiyama S, Ito K, Nakao A: TAOS1, a novel marker for advanced esophageal squamous cell carcinoma. Anticancer Res 2006, 26(3A):2029-2032.

80. Kohlhammer H, Schwaenen C, Wessendorf S, Holzmann K, Kestler HA, Kienle D, Barth TF, Moller P, Ott G, Kalla J, et al: Genomic DNA-chip hybridization in $\mathrm{t}(11 ; 14)$-positive mantle cell lymphomas shows a high frequency of aberrations and allows a refined characterization of consensus regions. Blood 2004, 104(3):795-801

81. Ronchetti D, Finelli P, Richelda R, Baldini L, Rocchi M, Viggiano L, Cuneo A, Bogni S, Fabris S, Lombardi L, et al: Molecular analysis of $11 \mathrm{q} 13$ breakpoints in multiple myeloma. Blood 1999, 93(4):1330-1337.

82. Fenton JA, Pratt G, Rothwell DG, Rawstron AC, Morgan GJ: Translocation $t(11 ; 14)$ in multiple myeloma: Analysis of translocation breakpoints on $\operatorname{der}(11)$ and der(14) chromosomes suggests complex molecular mechanisms of recombination. Genes Chromosomes Cancer 2004 39(2):151-155

83. Tarsitano M, Palmieri S, Ferrara F, Riccardi C, Cavaliere ML, Vicari L: Detection of the $t(11 ; 14)(q 13 ; q 32)$ without CCND1/IGH fusion in a case of acute myeloid leukemia. Cancer Genet Cytogenet 2009, 195(2):164-167.

84. Medeiros $\sqcup$, Carr J: Overview of the role of molecular methods in the diagnosis of malignant lymphomas. Arch Pathol Lab Med 1999, 123(12):1189-1207.

85. Janssen JW, Vaandrager JW, Heuser T, Jauch A, Kluin PM, Geelen E, Bergsagel PL, Kuehl WM, Drexler HG, Otsuki T, et al: Concurrent activation of a novel putative transforming gene, myeov, and cyclin D1 in a subset of multiple myeloma cell lines with $\mathrm{t}(11 ; 14)(\mathrm{q} 13 ; \mathrm{q} 32)$. Blood 2000, 95(8):2691-2698.

86. Wlodarska I, Meeus P, Stul M, Thienpont L, Wouters E, Marcelis L, Demuynck $H$, Rummens $J L$, Madoe V, Hagemeijer A: Variant $t(2 ; 11)(p 11 ; q 13)$ associated with the IgK-CCND1 rearrangement is a recurrent translocation in leukemic small-cell B-non-Hodgkin lymphoma. Leukemia 2004, 18(10):1705-1710.

87. de Oliveira FM, Tone LG, Simoes BP, Falcao RP, Brassesco MS, SakamotoHojo ET, dos Santos GA, Marinato AF, Jacomo RH, Rego EM: Acute myeloid leukemia (AML-M2) with $\mathrm{t}(5 ; 11)(\mathrm{q} 35 ; \mathrm{q} 13)$ and normal expression of cyclin D1. Cancer Genet Cytogenet 2007, 172(2):154-157.

88. Jhang JS, Narayan G, Murty W, Mansukhani MM: Renal oncocytomas with 11 q13 rearrangements: cytogenetic, molecular, and immunohistochemical analysis of cyclin D1. Cancer Genet Cytogenet 2004, 149(2):114-119. 
89. Wells RA, Hummel JL, De Koven A, Zipursky A, Kirby M, Dube I, Kamel-Reid S: A new variant translocation in acute promyelocytic leukaemia: molecular characterization and clinical correlation. Leukemia 1996, 10(4):735-740.

90. Wells RA, Catzavelos C, Kamel-Reid S: Fusion of retinoic acid receptor alpha to NuMA, the nuclear mitotic apparatus protein, by a variant translocation in acute promyelocytic leukaemia. Nat Genet 1997 17(1):109-113.

91. Sukhai MA, Wu X, Xuan Y, Zhang T, Reis PP, Dube K, Rego EM, Bhaumik M, Bailey DJ, Wells RA, et al: Myeloid leukemia with promyelocytic features in transgenic mice expressing hCG-NuMA-RARalpha. Oncogene 2004 23(3):665-678

92. Imagama S, Abe A, Suzuki M, Hayakawa F, Katsumi A, Emi N, Kiyoi H, Naoe T: LRP16 is fused to RUNX1 in monocytic leukemia cell line with $t(11 ; 21)$ (q13;q22). Eur J Haematol 2007, 79(1):25-31.

93. Sarova I, Brezinova J, Zemanova Z, Gancarcikova M, Vydra J, Cermak J, Michalova K: A novel gene LRP5 on 11q13.2 is rearranged in two patients with acute myeloid leukemia. Leuk Res 2011, 35(11):200-20.

94. Jesudasan RA, Rahman RA, Chandrashekharappa S, Evans GA, Srivatsan ES: Deletion and translocation of chromosome 11q13 sequences in cervical carcinoma cell lines. Am J Hum Genet 1995, 56(3):705-715.

95. Rao PH, Harris CP, Yan Lu X, Li XN, Mok SC, Lau CC: Multicolor spectral karyotyping of serous ovarian adenocarcinoma. Genes Chromosomes Cancer 2002, 33(2):123-132.

96. Wong N, Lai P, Pang E, Leung TW, Lau JW, Johnson PJ: A comprehensive karyotypic study on human hepatocellular carcinoma by spectral karyotyping. Hepatology 2000, 32(5):1060-1068.

97. Yamashita Y, Nishida K, Okuda T, Nomura K, Matsumoto Y, Mitsufuji S, Horiike S, Hata H, Sakakura C, Hagiwara A, et al: Recurrent chromosomal rearrangements at bands $8 \mathrm{q} 24$ and $11 \mathrm{q} 13$ in gastric cancer as detected by multicolor spectral karyotyping. World J Gastroenterol 2005, 11(33):5129-5135.

98. Shuster MI, Han L, Le Beau MM, Davis E, Sawicki M, Lese CM, Park NH, Colicelli J, Gollin SM: A consistent pattern of RIN1 rearrangements in oral squamous cell carcinoma cell lines supports a breakage-fusion-bridge cycle model for 11q13 amplification. Genes Chromosomes Cancer 2000, 28(2):153-163.

99. Martin CL, Reshmi SC, Ried T, Gottberg W, Wilson JW, Reddy JK, Khanna P, Johnson JT, Myers EN, Gollin SM: Chromosomal imbalances in oral squamous cell carcinoma: examination of 31 cell lines and review of the literature. Oral Oncol 2008, 44(4):369-382.

100. Mishmar D, Rahat A, Scherer SW, Nyakatura G, Hinzmann B, Kohwi Y Mandel-Gutfroind Y, Lee JR, Drescher B, Sas DE, et al: Molecular characterization of a common fragile site (FRA7H) on human chromosome 7 by the cloning of a simian virus 40 integration site. Proc Natl Acad Sci U S A 1998, 95(14):8141-8146.

101. Albertson DG: Gene amplification in cancer. Trends Genet 2006 22(8):447-455.

102. Reshmi SC, Roychoudhury S, Yu Z, Feingold E, Potter D, Saunders WS, Gollin SM: Inverted duplication pattern in anaphase bridges confirms the breakage-fusion-bridge (BFB) cycle model for 11q13 amplification. Cytogenet Genome Res 2007, 116(1-2):46-52.

103. Gajduskova P, Snijders AM, Kwek S, Roydasgupta R, Fridlyand J, Tokuyasu T, Pinkel D, Albertson DG: Genome position and gene amplification. Genome Biol 2007, 8(6):R120.

104. Coquelle A, Pipiras E, Toledo F, Buttin G, Debatisse M: Expression of fragile sites triggers intrachromosomal mammalian gene amplification and sets boundaries to early amplicons. Cell 1997, 89(2):215-225.

105. Huang X, Gollin SM, Raja S, Godfrey TE: High-resolution mapping of the $11 q 13$ amplicon and identification of a gene, TAOS1, that is amplified and overexpressed in oral cancer cells. Proc Natl Acad Sci U S A 2002, 99(17):11369-11374.

106. Tada K, Oka M, Tangoku A, Hayashi H, Oga A, Sasaki K: Gains of 8q23-qter and $20 \mathrm{q}$ and loss of 11q22-qter in esophageal squamous cell carcinoma associated with lymph node metastasis. Cancer 2000, 88(2):268-273.

107. Takeshita H, Ichikawa D, Komatsu S, Tsujiura M, Kosuga T, Deguchi K, Konishi H, Morimura R, Shiozaki A, Fujiwara H, et al: Prediction of CCND1 amplification using plasma DNA as a prognostic marker in oesophageal squamous cell carcinoma. Br J Cancer 2010, 102(9):1378-1383.

108. Muller D, Millon R, Velten M, Bronner $G$, Jung $G$, Engelmann A, Flesch $H$, Eber M, Methlin G, Abecassis J: Amplification of 11 q13 DNA markers in head and neck squamous cell carcinomas: correlation with clinical outcome. Eur J Cancer 1997, 33(13):2203-2210

109. Miyamoto R, Uzawa N, Nagaoka S, Nakakuki K, Hirata Y, Amagasa T: Potential marker of oral squamous cell carcinoma aggressiveness detected by fluorescence in situ hybridization in fine-needle aspiration biopsies. Cancer 2002, 95(10):2152-2159.

110. Sugahara K, Michikawa Y, Ishikawa K, Shoji Y, Iwakawa M, Shibahara T, Imai $\mathrm{T}$ : Combination effects of distinct cores in 11q13 amplification region on cervical lymph node metastasis of oral squamous cell carcinoma. Int J Oncol 2011, 39(4):761-769.

111. Huang X, Godfrey TE, Gooding WE, McCarty KS Jr, Gollin SM: Comprehensive genome and transcriptome analysis of the $11 q 13$ amplicon in human oral cancer and synteny to the 7F5 amplicon in murine oral carcinoma. Genes Chromosomes Cancer 2006, 45(11):1058-1069.

112. Fortin A, Guerry M, Guerry R, Talbot M, Parise O, Schwaab G, Bosq J, Bourhis J, Salvatori $P$, Janot $F$, et al: Chromosome $11 q 13$ gene amplifications in oral and oropharyngeal carcinomas: no correlation with subclinical lymph node invasion and disease recurrence. Clin Cancer Res 1997, 3(9):1609-1614

113. Xia J, Chen Q, Li B, Zeng X: Amplifications of TAOS1 and EMS1 genes in oral carcinogenesis: association with clinicopathological features. Oral Oncol 2007, 43(5):508-514.

doi:10.1186/1471-2407-12-367

Cite this article as: Hao et al:: Characterization of genetic

rearrangements in esophageal squamous carcinoma cell lines by a combination of M-FISH and array-CGH: further confirmation of some split genomic regions in primary tumors. BMC Cancer 2012 12:367.

\section{Submit your next manuscript to BioMed Central and take full advantage of:}

- Convenient online submission

- Thorough peer review

- No space constraints or color figure charges

- Immediate publication on acceptance

- Inclusion in PubMed, CAS, Scopus and Google Scholar

- Research which is freely available for redistribution 